Article

\title{
Improved Thermophysical Properties and Energy Efficiency of Aqueous Ionic Liquid/MXene Nanofluid in a Hybrid PV/T Solar System
}

\author{
Likhan Das ${ }^{1}$, Khairul Habib ${ }^{1, *}$, R. Saidur ${ }^{2,3}$, Navid Aslfattahi ${ }^{4}{ }^{(0)}$, Syed Mohd Yahya ${ }^{5}{ }^{(\mathbb{D}}$ and \\ Fazlay Rubbi ${ }^{1}$ \\ 1 Department of Mechanical Engineering, Universiti Teknologi PETRONAS, Bandar Seri Iskandar, Perak \\ Darul Ridzuan 32610, Malaysia; likhan.das11@gmail.com (L.D.); mdfrs22@gmail.com (F.R.) \\ 2 Research Centre for Nanomaterials and Energy Technology (RCNMET), School of Science and Technology, \\ Sunway University, Petaling Jaya 47500, Malaysia; saidur@sunway.edu.my \\ 3 Department of Engineering, Lancaster University, Lancaster LA1 4YW, UK \\ 4 Department of Mechanical Engineering, Faculty of Engineering, University of Malaya, Kuala Lumpur 50603, \\ Malaysia; navid.fth87@yahoo.com \\ 5 Sustainable Energy and Acoustics Research Lab, Mechanical Engineering Department, \\ Aligarh Muslim University, Aligarh 202002, India; smyahya@zhcet.ac.in \\ * Correspondence: khairul.habib@utp.edu.my; Tel.: +60-102-442-375
}

Received: 21 May 2020; Accepted: 17 June 2020; Published: 14 July 2020

\begin{abstract}
In recent years, solar energy technologies have developed an emerging edge. The incessant research to develop a power source alternative to fossil fuel because of its scarcity and detrimental effects on the environment is the main driving force. In addition, nanofluids have gained immense interest as superior heat transfer fluid in solar technologies for the last decades. In this research, a binary solution of ionic liquid (IL) + water based ionanofluids is formulated successfully with two dimensional MXene $\left(\mathrm{Ti}_{3} \mathrm{C}_{2}\right)$ nano additives at three distinct concentrations of $0.05,0.10$, and $0.20 \mathrm{wt} \%$ and the optimum concentration is used to check the performance of a hybrid solar PV/T system. The layered structure of MXene and high absorbance of prepared nanofluids have been perceived by SEM and UV-vis respectively. Rheometer and DSC are used to assess the viscosity and heat capacity respectively while transient hot wire technique is engaged for thermal conductivity measurement. A maximum improvement of $47 \%$ in thermal conductivity is observed for $0.20 \mathrm{wt} \%$ loading of MXene. Furthermore, the viscosity is found to rise insignificantly with addition of $\mathrm{Ti}_{3} \mathrm{C}_{2}$ by different concentrations. Conversely, viscosity decreases substantially as the temperature increases from $20{ }^{\circ} \mathrm{C}$ to $60{ }^{\circ} \mathrm{C}$. However, based on their thermophysical properties, $0.20 \mathrm{wt} \%$ is found to be the optimum concentration. A comparative analysis in terms of heat transfer performance with three different nanofluids in PV/T system shows that, IL+ water/MXene ionanofluid exhibits highest thermal, electrical, and overall heat transfer efficiency compared to water/alumina, palm oil/MXene, and water alone. Maximum electrical efficiency and thermal efficiency are recorded as $13.95 \%$ and $81.15 \%$ respectively using IL + water/MXene, besides that, heat transfer coefficients are also noticed to increase by $12.6 \%$ and $2 \%$ when compared to water/alumina and palm oil/MXene respectively. In conclusion, it can be demonstrated that MXene dispersed ionanofluid might be great a prospect in the field of heat transfer applications since they can augment the heat transfer rate considerably which improves system efficiency.
\end{abstract}

Keywords: MXene; ionic liquid; nanofluids; thermophysical properties; PV/T system 


\section{Introduction}

Since the industrial revolution, the demand for energy has been increasing day by day, thus it is anticipated that global energy demand will grow up to $30 \%$ by the year 2040 as stated in the World Energy Report, 2019 by the International Energy Agency, (IEA) [1,2]. To meet this growing energy demand, fossil fuels are being brunt to a large extent, accounting for $87 \%$ of total energy supply. On this basis, the need for renewable energy resources is sought after due to the massive consumption of fossil fuels. Moreover, burning of these hydrocarbon deposits has a detrimental effect on the environment and global climate. Therefore, scientists are enforcing their efforts on proper utilization of green and renewable sources of energy mostly on solar, wind, tides, and geothermal energy [3]. Solar energy is considered the best alternative to supplement the consumption of fossil fuels in fulfilling energy demand. Furthermore, it is the most compelling source of renewable energy which can be utilized through numerous and ever-growing solar energy technologies-including solar thermal collectors, artificial photosynthesis, photovoltaics, solar ponds, and concentrating solar power plants [4-6]. Hybrid PV/T is a solar cogeneration approach that utilizes solar radiation and heat, producing both electrical and thermal energy. PV/T systems have gained immense popularity for residential and commercial applications because of their greenness and eco-friendly operation. The effectiveness of PV/T systems varies with several considerations such as incident angle of solar light, material, design, and working fluids $[7,8]$. Improving the thermal and optical properties of heat transfer fluid (HTF) is considered as the most convenient ways that augments the overall effectiveness of PV/T system. Water, thermal oil, ethylene glycol (EG), and ionic liquid are being employed as conventional working fluids in a hybrid solar PV/T system. Inclusion of solid nanoparticles into the heat transfer fluids can substantially improve optical and thermophysical properties [9-11]. The inclusion of nano-sized solid particles into base fluids, referred to as 'nanofluids', significantly alters thermophysical properties of the base liquids especially thermal conductivity [12-16]. Choi and Eastman [17] were the pioneers who coined the term "nanofluid". Nanofluids have gained plenty of interest in recent decades as they have superior heat transport properties and also hold astounding possibilities in many clean engineering applications [18-20]; therefore, it is deemed to be the HTF for the next generation [21]. To date, researchers have conducted numerous investigations to improve the thermophysical properties of conventional HTFs by dispersing distinct nano additives such as metals, their carbides, oxides, or carbon nanotubes (CNTs) [22-24]. Recently, carbon-based nanoparticles and two-dimensional nanostructures have captivated ample attention due to their comparatively higher thermal conductivity, greater specific surface area, better compatibility with base fluid, better lubricating property, and ample availability when compared with other nanoparticles [25,26]. A broad number of studies were performed with graphite [27], carbon nanotubes(CNTs) [28,29], graphene [30], graphene oxide (GO) [31], nano diamond [32], and graphite flake [33] nanoparticles so far. Yu et al. [34] experimentally measured the thermal conductivity of EG based nanofluid with GO nanosheets where thermal conductivity was noticeably higher by $61 \%$ compared to pure EG, while the nanosheet concentration was 5 vol \%. In another experimental work by Baby and Ramaprabhu [35], thermal conductivity of EG/graphene and water/graphene nanofluids were measured by transient hot wire method. Based on their observation, maximum improvement was about $64 \%$ at $50{ }^{\circ} \mathrm{C}$ when $0.056 \mathrm{vol} \%$ of functionalized $2 \mathrm{D}$ graphene was dispersed into deionized water. In another investigation, Wang et al. [36] experimentally inspected the influence of $2 \mathrm{D}$ graphene nanoparticles on thermophysical properties of ionic liquid [HMIM] $\mathrm{BF}_{4}$ and demonstrated that $18.6 \%$ improvement in the thermal conductivity was attained at $65{ }^{\circ} \mathrm{C}$ with nanoparticle loading as low as of $0.06 \mathrm{wt} \%$ while no significant decrease in specific heat was observed. Unpredictably, viscosity of synthesized nanofluids was found to be lowered than base fluids which could be ascribed to the self-lubricating property of graphene. Apart from this, an opulent number of studies were also carried out with imidazolium ionic liquid based (IL) nanofluids [37,38], concluding that imidazolium based ILs can be employed as an excellent base fluids due to their salient features like non volatility, high thermal stability, and good interaction with carbon-based nanoparticles [39]. Plentiful studies are found in the literature that find numerous nanofluids improve the heat transport 
efficiency of PV/T system [40-42]. Sardarabadi et al. [43] performed an experimental investigation to check the performance of a PV/T system using water/silica $\left(\mathrm{SiO}_{2}\right)$ nanofluids with two different concentrations of $1 \mathrm{wt} \%$ and $3 \mathrm{wt} \%$. The overall energy efficiency and thermal efficiency of the $\mathrm{PV} / \mathrm{T}$ collector increased by $7.9 \%$ and $12.8 \%$ using nanofluid of $3 \mathrm{wt} \%$, while for $1 \%$ they were found to have increased by $3.6 \%$ and $7.6 \%$ than pure water. In another study, phase change material (PCM) along with $\mathrm{ZnO} /$ water nanofluid were used in a solar PV/T module as coolant medium to see the simultaneous effect experimentally [44]. To accomplish this, they designed two systems: one with phase change material PCM, PCM/(PV/T); and PV/T only. PCM/nanofluid based PV/T system was subjected to $13 \%$ increment in electrical efficiency compared to a typical PV/T system, while an almost $9 \%$ augmentation in thermal efficiency was also noticed together with more than $23 \%$ overall exergy efficiency enhancement. Recently, Abdallah et al. [41] studied a PV/T system with MWCNT (multi-wall carbon nanotube)/water nanofluids to investigate the electrical and thermal efficiency. The findings demonstrated that adding nanoparticles into the water had prompted the enhancement of the thermophysical properties of the working fluid which further increased the overall efficiency of the system. For different particles concentration ratio varying from 0 to $0.3 \mathrm{vol} \%$ of MWCNT, the analyzed results reported that nanofluids with $0.075 \mathrm{vol} \%$ of MWCNT exhibited the best performances, reducing the panel temperature by $12{ }^{\circ} \mathrm{C}$ that led $83.26 \%$ overall system efficiency at maximum incident radiation. In addition, $\mathrm{Al}_{2} \mathrm{O}_{3} /$ water, $\mathrm{TiO}_{2} /$ water [45], $\mathrm{Ag} /$ water [42], sand-propylene glycol/water [46], and $\mathrm{Fe}_{3} \mathrm{O}_{4}$ /water [47] were also explored to check their performance in PV/T systems in some studies. Reviewing the findings from literature, it can be attained that all relevant studies mainly focused on the optimization of solar PV/T systems using water-based nanofluid. Although overall thermal efficiency in some studies was satisfactory, they were only applicable at lower temperature ranges as water becomes thermally volatile at higher temperatures. Furthermore, variation in PV panel temperature and alteration of solar radiation were not studied in most cases. Therefore, it necessitates further studies with the aim of developing more promising nanofluids for solar PV/T system. MXene is a new family of 2D inorganic nanocomposite like graphene consisting of nano-sized layers of early transition metal carbides, carbonitrides, and nitrides [48]. MXene has a common formula of $\mathrm{M}_{n+1} \mathrm{X}_{n} \mathrm{~T}_{x}$ $(n=1,2$, and 3) which is synthesized from 3-D MAX phases [49] by selective etching of ' $\mathrm{A}$ ' layer which is placed for a group IIIA or IVA element, $\mathrm{M}$ symbolizes early transition metal, $\mathrm{T}_{\mathrm{x}}$ represents the surface termination (e.g., F, O, and $\mathrm{OH}$ ) and $\mathrm{X}$ can be either carbon or nitrogen [50]. Since the surface termination/elemental composition is changeable [51], the properties of MXene can be altered rapidly, therefore rendering MXene more attractive than graphene. MXene has received immense research interest in numerous disciplines, such as nanomedicine, biosensors, electrochemical energy storage, and photothermal conversions [52-54]. In the present research, the authors formulate a novel ionanofluid with MXene and ionic liquid aqueous solution. The inclusion of 2D MXene into ionic liquid solutions has formulated a new class of ionanofluid. To the best of the authors' knowledge, this is the first time MXene dispersed ionanofluid has been formulated successfully and its heat transfer behavior on a hybrid PV/T has been investigated. It will certainly be helpful for researchers and guide them in further investigations with this novel nanomaterial in heat transfer applications. Thermal conductivity, specific heat capacity, density, and assessments for this novel IL+ water/MXene are studied for the first time to the best of the authors' knowledge. Thermal and electrical performance evaluation considering variable conditions (temperature, solar radiation) with this novel nanofluid in a hybrid PV/T solar system are new findings of this research work as well. Firstly, the authors formulate and characterize nanofluids and therefore, determine best concentration at which thermophysical properties are optimum. In consideration of their thermophysical properties, the authors favorably considered its possible application in hybrid PV/T system which could potentially serve as a more efficient alternative as heat transfer fluid for the application in hybrid PV/T solar system. 


\section{Materials, Methods, and Preparation}

\subsection{Materials}

Ionic Liquid [MMIM][DMP] (1,3-Dimethylimidazolium dimethyl-phosphate) was supplied by Merck KGaA, Darmstadt, Germany. Table 1 represents the specifications of certificate analysis of [MMIM][DMP]. No further purification was accomplished during the sample preparation. Highly purified deionized water (Purity $\geq 99.998 \%$ ) was prepared at nanomaterial research Centre of Sunway University, Malaysia.

Table 1. Properties of [MMIM][DMP].

\begin{tabular}{cc}
\hline Property & [MMIM][DMP] \\
\hline Purity (HPLC) & $\geq 98.0 \%$ \\
Identity (NMR) & passed \\
Density & $1.27 \mathrm{~g} / \mathrm{cm}^{3}\left(20^{\circ} \mathrm{C}\right)$ \\
Water (KF) & $\leq 0.1 \%$ \\
Halides (IC) & $\leq 0.1 \%$ \\
Color & Yellow \\
\hline
\end{tabular}

\subsection{Synthesis of MXene $\left(\mathrm{Ti}_{3} \mathrm{C}_{2}\right)$}

In the synthesis of MXene $\left(\mathrm{Ti}_{3} \mathrm{C}_{2} \mathrm{~T}_{x}\right)$, the following materials were used without any further purification: MAX Phase material $\left(\mathrm{Ti}_{3} \mathrm{AlC}_{2}\right)$ from Y-Carbon Ltd., Ammonium hydrogen difluoride (reagent grade 95\%, Sigma Aldrich, Kuala Lumpur, Malaysia) and sodium hydroxide (97\% purity, pellets, Sigma Aldrich) were obtained. Firstly, a solution of $2 \mathrm{M}$ and $\mathrm{NH}_{4} \mathrm{HF}_{2}$ was prepared precisely as the main part of the wet chemistry etching process. Afterwards, the dilution process of the ammonium hydrogen difluoride was conducted using DI water to produce $20 \mathrm{ml}$ of solution, followed by magnet-stirring at $300 \mathrm{rpm}$ for $1 \mathrm{~h}$ and at room temperature using hot plate magnet stirrer (RCT BASIC, IKA, Staufen, Germany). $1 \mathrm{~g}$ of $\mathrm{Ti}_{3} \mathrm{AlC}_{2}$ was weighed using microbalance (Explorer series, EX224, Ohaus, Parsippany, NJ, USA), then added to the uniform well-prepared $\mathrm{NH}_{4} \mathrm{HF}_{2}$ solution. Adding the MAX phase material to the prepared solution was performed slowly as the reaction is exothermic. The MAX phase suspension in the $\mathrm{NH}_{4} \mathrm{HF}_{2}$ was magnet-stirred at $300 \mathrm{rpm}$ for $48 \mathrm{~h}$ and room temperature continuously to conduct the etching process. After the etching process, a dilute solution of $\mathrm{NaOH}$ was poured until the $\mathrm{pH}$ of the suspension reached 6 and was filtered and rinsed several times with deionized water. The washing process was conducted using an ultrahigh centrifuge (Sorvall LYNX 6000, Thermo Scientific, Waltham, MA, USA) four times (10 m each times) at $3500 \mathrm{rpm}$. The achieved multilayered MXene $\left(\mathrm{m}-\mathrm{Ti}_{3} \mathrm{C}_{2}\right)$ was then sonicated for $1 \mathrm{~h}$ by means of ultrasonic probe sonicator ('FS-1200N') to obtain delaminated flakes of the MXene $\left(\mathrm{d}-\mathrm{Ti}_{3} \mathrm{C}_{2}\right)$. The synthesized delaminated flakes of MXene nanomaterial was dried in a vacuum oven (VO 500, MEMMERT Germany, Schwabach, Germany) overnight.

\subsection{Preparation of Ionanofluid}

The formulation of ionanofluid samples was accomplished by dispersion of $\mathrm{Ti}_{3} \mathrm{C}_{2}$ nanoparticles into IL aqueous solution precisely. To achieve this, IL aqueous solution was prepared by dissolving 20 vol \% of [MMIM][DMP] into $80 \mathrm{vol} \%$ of deionized water by magnetic stirring for $30 \mathrm{~m}$ at $45^{\circ} \mathrm{C}$ and $700 \mathrm{rpm}$ to obtain a homogenous mixture. The viscosity of the ionic liquid is high; therefore, adding water contributes to reducing the viscosity of the solutions. Furthermore, strong hydrophilicity of MXene will offer better stability with adding water [55]. Firstly, $\mathrm{Ti}_{3} \mathrm{C}_{2}$ nanosheet was precisely weighted using an analytical microbalance (Ohaus, Model: Ex224, accuracy: $0.0001 \mathrm{~g}$, Parsippany, NJ, USA) and directly added into the IL solutions at three different concentrations of $0.05,0.10$, and $0.20 \mathrm{wt} \%$. Next, all sample solutions were stirred using hot plate magnetic stirrer (RCT basic IKAMAG ${ }^{\circledR}$ safety control, Staufen, Germany) for $1 \mathrm{~h}$ at $50^{\circ} \mathrm{C}$ and $700 \mathrm{rpm}$. Finally, followed by an ultrasonic dispersion using a 
1200 W, 20 kHz ultra sonicator (Ultrasonic Probe sonicator, Model: Fs-1200N, Hangzhou, China) for $30 \mathrm{~m}$, a stable and well dispersed ionanofluid was formed by interrupting the hard agglomeration of MXene particles.

\subsection{Characterization}

The surface morphology of $\mathrm{Ti}_{3} \mathrm{C}_{2}$ nanosheet was inspected with a SEM (scanning electron microscopy) "Tescan, Model: Vega, Brno, Czech Republic". The SEM device was operated at $15 \mathrm{kV}$ voltage and $10 \mathrm{~mA}$ current to obtain accurate and sharp images. In order to inspect the layered structure of $\mathrm{Ti}_{3} \mathrm{C}_{2}$, a sample area having significant number of layers was examined using SEM. Fourier transform infrared (FTIR) spectroscopy (Perkin Elmer ${ }^{\circledR}$, Model: Spectrum Two ${ }^{\text {TM }}$, Waltham, MA, USA) was employed to identify the chemical compositions and functional groups of the formulated nanofluids. The device was operated at a resolution of $4 \mathrm{~cm}^{-1}$ and each spectrum was obtained over 16 scans with a scan speed 0.2. The spectra were determined for infrared frequency region ranging from 400 to $4000 \mathrm{~cm}^{-1}$. Quantitative absorbance of all samples was measured as a function of wavelength using a UV-vis spectrometer (Perkin Elmer ${ }^{\circledR}$, Model: Lambda 750, Waltham, MA, USA)

\subsection{Thermophysical Properties Measurement}

\subsubsection{Thermal Conductivity}

To assess the thermal conductivity, a transient hot wire method operated thermal property analyzer (Model: Tempos, Pullman, WA, USA) was employed affording an accuracy of $< \pm 10 \%$ for each sample. A $6 \mathrm{~cm}, \mathrm{Ks}-3$ sensor based single heated needle was employed to detect the temperature by dipping the needle into the sample inside a hot water bath. Before measuring the thermal conductivity, the device was calibrated precisely using pure glycerin at $20^{\circ} \mathrm{C}$. The calibration details are given in Table 2 and an illustration of the used setup is shown in Figure 1. Before taking each reading, the samples were equilibrated for at least $10 \mathrm{~min}$ as temperature reaches the anticipated value. The precision of measurement was confirmed by repeating each measurement for 5 times and taking the mean value of iterations.

Table 2. Calibration details of Tempos thermal conductivity analyzer.

\begin{tabular}{cccc}
\hline Standard Sample & $\mathbf{K}_{\text {measured }}$ & $\begin{array}{c}\mathbf{K}_{\text {reference }} \\
\mathbf{W m}^{-\mathbf{1}} \mathbf{k}^{-\mathbf{1}}\end{array}$ & Standard Deviation $\boldsymbol{\sigma k}$ \\
\hline Glycerin $\left(20^{\circ} \mathrm{C}\right)$ & 0.289 & 0.282 & \pm 0.038 \\
\hline
\end{tabular}

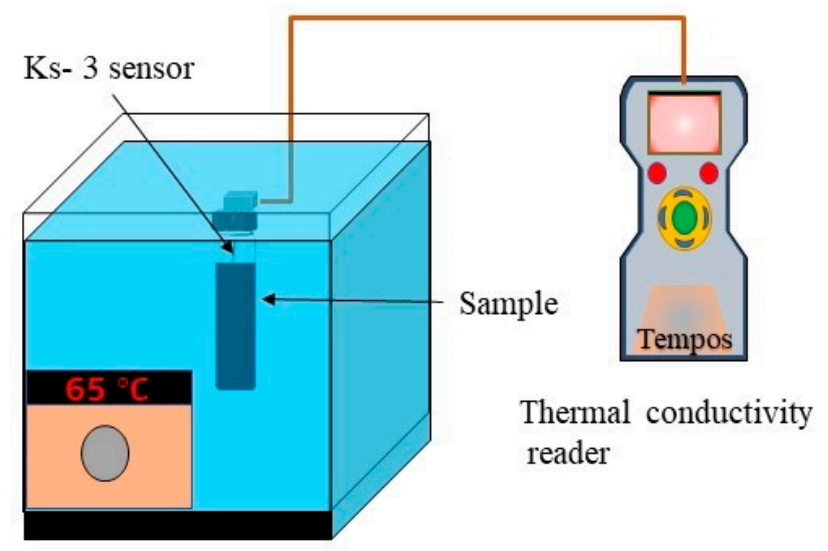

Constant Temperature water bath

Figure 1. Setup used for measuring thermal conductivity. 


\subsubsection{Specific Heat Capacity}

In this study, the specific heat capacity $\left(c_{\mathrm{p}}\right)$ measurements of all samples were obtained using a (DSC). DSC-1000/C (Linseis, Germany), is a high resolution $(0.03 \mu \mathrm{W})$ instrument and the measurements are conducted using an aluminum crucible of $40 \mu \mathrm{L}$. The temperature ranges from $26^{\circ} \mathrm{C}$ to $60{ }^{\circ} \mathrm{C}$ with the heating rate of $10^{\circ} \mathrm{C} / \mathrm{min}$. The synthesized samples are tightly sealed in a regular aluminum crucible with the capacity of $40 \mu \mathrm{L}$ under a $\mathrm{N}_{2}$ ambiance with a flow rate of $20 \mathrm{ml} / \mathrm{min}$. The repeatability and calorimetric precision of temperature are $\pm 0.1{ }^{\circ} \mathrm{C}$ and $\pm 1 \%$, respectively. Temperature and enthalpy calibrations for DSC are carried out employing four standard reference samples (indium, tin, lead, and zinc) provided by the supplier. One uniform protocol for $c_{\mathrm{p}}$ measurements of the nanofluid samples are adjusted to validate the precision of results. However, the measurement uncertainty ranged from $0.2 \%$ to a maximum $0.8 \%$.

\subsubsection{Measurement of Viscosity}

A rheometer (Anton Paar, Model: MCR 92, Graz, Austria) was employed to measure the viscosity of the samples at a revolution rate of $100 \mathrm{rpm}$. Accuracy of the measurement was $\pm 1.0 \%$ (in the range of -40 to $200^{\circ} \mathrm{C}$ temperature) as stated by product specification. Viscosity of each sample was measured for the temperature range from $20^{\circ} \mathrm{C}$ to $50^{\circ} \mathrm{C}$.

\subsubsection{Measurement of Density}

A densitometer (Anton Paar, Density Meter, Model: DMA ${ }^{\mathrm{TM}} 1001, \mathrm{Graz}$, Austria) was employed to measure the temperature depended density. The densitometer was calibrated with air and pure distilled water by performing air test and water test respectively. The density of the sample was taken as a function of temperature from $20^{\circ} \mathrm{C}$ to $60^{\circ} \mathrm{C}$ with an accuracy of $0.0001 \mathrm{~g} / \mathrm{cm}^{3}$ and repeatability of at $0.00005 \mathrm{~g} / \mathrm{cm}^{3}$.

\subsubsection{Measurement of Thermal Stability}

The thermogravimetric analysis (TGA) was performed to measure the thermal stability of each sample, showing the weight decomposition as a function of temperature. The analysis was performed with thermogravimetric analyzer (Perkin Elmer ${ }^{\circledR}$, Model: TGA 4000, Waltham, MA, USA). All the samples were heated from $30^{\circ} \mathrm{C}$ to $500^{\circ} \mathrm{C}$ in a compact ceramic furnace with a heating rate of $10{ }^{\circ} \mathrm{C} / \mathrm{min}$ and a flow rate of $19.8 \mathrm{ml} / \mathrm{min}$ of $\mathrm{N}_{2}$ at 1.9 bar.

\subsubsection{Measurement of Zeta Potential}

Zeta potential is a common technique to measure the stability of nanofluids and colloidal solutions [56]. To assess the zeta potential measurement of the prepared ionanofluids at different concentrations, a particle analyzer (Litesizer-500, Anton paar, Graz, Austria) was employed. The measurements were repeated for at least three times for each sample.

\subsection{Physical Model of PV/T System}

In a hybrid PV/Thermal system for controlling the temperature rise of PV module various active and passive techniques were employed by researchers. Many of them used nanofluid as a coolant at the back of the PV panel to lower the temperature, especially in hot arid climate for better electrical efficiency. The specification of PV panel used for simulation purpose in PV/thermal system is listed in Table 3. 
Table 3. Specification of PV panel.

\begin{tabular}{cc}
\hline Make and Model No. & Vikram Solar, ELDORA VSP.72.AAA.03 \\
\hline Material & Polycrystalline Silicon Cell \\
\hline Dimension & $1955 \times 982 \times 36 \mathrm{~mm}$ \\
No. of cells & 72 \\
Peak power & $300 \mathrm{~W}$ \\
Maximum Voltage (Vmpp) & $37.05 \mathrm{~V}$ \\
Maximum Current (Impp) & $8.10 \mathrm{~A}$ \\
Open circuit voltage (Voc) & $45.58 \mathrm{~V}$ \\
Short circuit current (Isc) & $8.58 \mathrm{~A}$ \\
Weight of PV module & $20.5 \mathrm{Kg}$ \\
Operating temperature range & $-40{ }^{\circ} \mathrm{C}$ to $+85{ }^{\circ} \mathrm{C}$ \\
Standard test condition (STC) & $1000 \mathrm{~W} / \mathrm{m}^{2}, \mathrm{AM} 1.5,25^{\circ} \mathrm{C}$ \\
\hline
\end{tabular}

In this part, a numerical investigation is carried out to assess the performance of newly developed ionic liquid solution/MXene based nanofluid in PV/T system. The proposed work consists of hybrid PV/T system in which alumina/water, MXene/palm oil and IL+ water/MXene based nanofluid were employed and their performance are compared with water alone as a coolant numerically. A typical model of a PV/T system is presented in Figure 2, where the red color path indicates the thermal circuit and another one indicates the electrical circuit.

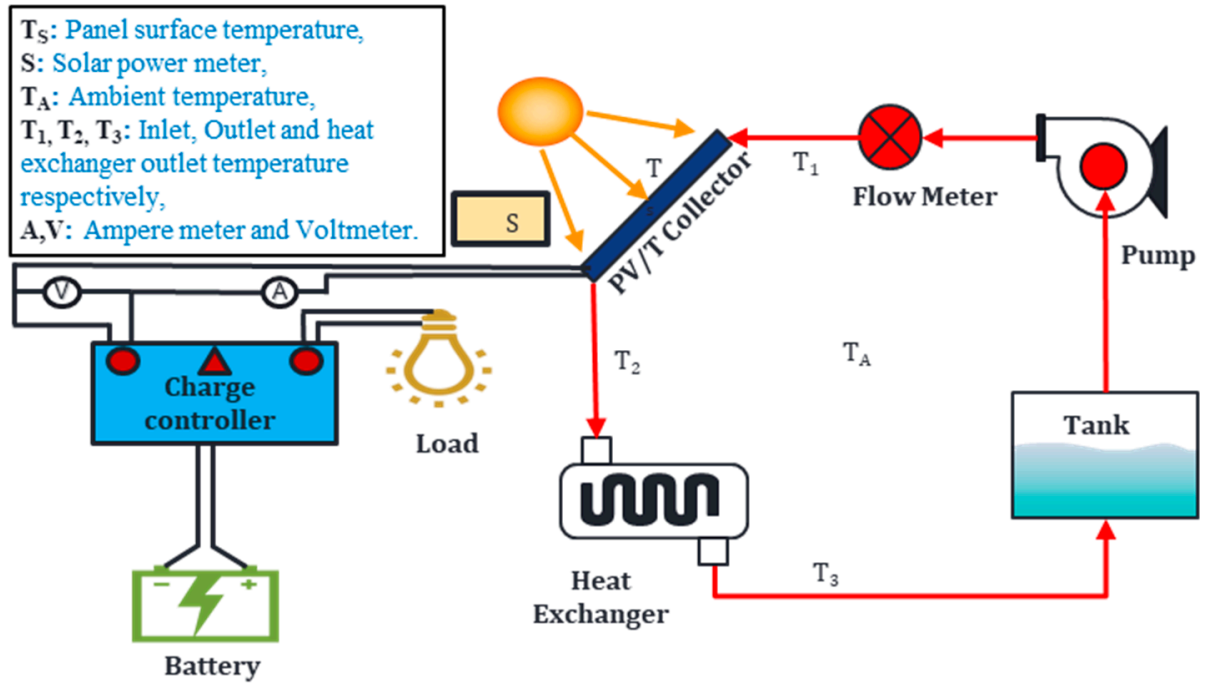

Figure 2. Typical model of a conventional PV/T system.

\subsection{Numerical Modeling of PV/T Solar System}

The problem under investigation comprises of PV module of 300 Watt which consist of four layers namely: PV solar cell, EVA (encapsulated vinyl acetate) on both sides of the solar cell, and a tedlar layer. Beneath the PV module, a heat exchanger in the form serpentine copper tubing is mounted (See Figure 3). The thicknesses of solar cell, EVA, and tedlar layers are $0.3 \mathrm{~mm}, 0.5 \mathrm{~mm}$, and $0.1 \mathrm{~mm}$ respectively, remaining dimensions are the same as the PV panel i.e. (1955 mm $\times 982 \mathrm{~mm}$ ). Finite element method-based Multiphysics software, COMSOL (Burlington, MA, USA) is used for numerical study. CFD and heat transfer modules of COMSOL are used to assess the performance parameters of PV/T system. It is assumed that the nanofluid flow is steady, three-dimensional, incompressible, and laminar. Transmissivity of EVA is about $100 \%$, the role of dust on PV surface absorptivity is assumes negligible and temperature variation along the thickness of PV module assume to be zero. Furthermore, homogeneous mixture of nanoparticles in the base fluid is assumed (i.e., no particle agglomeration). In this study, [MMIM][DMP]+water $/ \mathrm{Ti}_{3} \mathrm{C}_{2}$, palm oil/ $/ \mathrm{Ti}_{3} \mathrm{C}_{2}$ based nanofluid with 
$0.2 \mathrm{wt} \%$ nanoparticle concentration are used as thermal conductivity is highest at this concentration. Thermal conductivity corresponds to $0.2 \mathrm{wt} \%$, with different temperatures fitted to third order polynomial using regression analysis and inserted into a COMSOL environment using a user defined function. For alumina/water nanofluid, the Maxwell model is used for modelling thermal conductivity in which values of $0.611 \mathrm{~W} / \mathrm{m} . \mathrm{K}$ for water and $40 \mathrm{~W} / \mathrm{m} . \mathrm{K}$ for $\mathrm{Al}_{2} \mathrm{O}_{3}$ are used (see Equation (1)).

$$
k_{n f}=k_{b f} \frac{k_{s}+2 k_{b f}-2 \phi\left(k_{b f}+k_{s}\right)}{k_{s}+k_{b f}+2 \phi\left(k_{b f}+k_{s}\right)}
$$

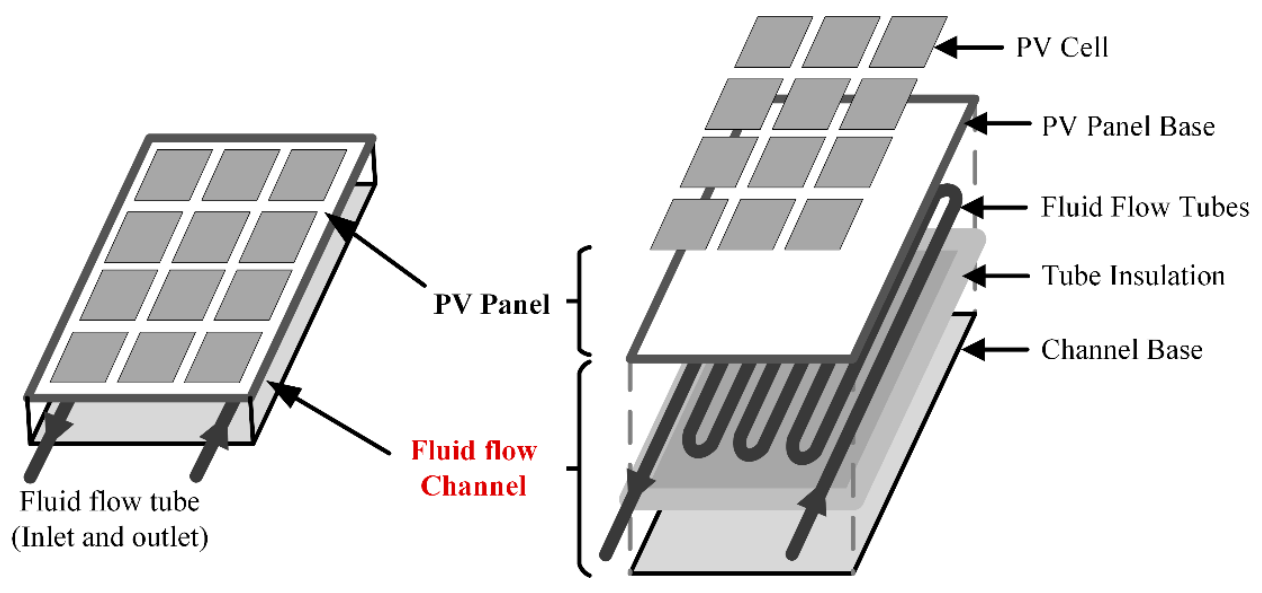

Figure 3. Schematic diagram of the proposed nanofluid backflow channel-based PV panel.

For modelling temperature dependent viscosity of IL+ water/MXene and palm oil/MXene nanofluids, regression analysis of experimental data is performed. For IL+ water/Mxene nanofluid, thermophysical properties are experimentally obtained in present studies while previous experimental data has been used for palm oil/MXene nanofluids for same operation conditions [24]. The equation is incorporated into COMSOL using UDF (user defined function), as with thermal conductivity, and used for simulation purpose. For $\mathrm{Al}_{2} \mathrm{O}_{3}$-water nanofluid Brinkman model is used for modelling viscosity. For solid domain in the PV/T system heat conduction equation is used to account for heat transfer. Thermal transport from PV panel surface to flow channel is solved by a heat conduction equation as shown below in Equations (2)-(4).

$$
-\left(\frac{k}{\rho C_{p}}\right)\left(\frac{\partial^{2} T}{\partial x^{2}}+\frac{\partial^{2} T}{\partial y^{2}}+\frac{\partial^{2} T}{\partial z^{2}}\right)=\alpha_{p} G-E_{e}-h_{\text {panel-ted }}\left(T_{\text {penal }}-T_{\text {ted }}\right)
$$

The equation shows heat transfer from the PV panel to tedlar layer. Similarly, other thermal energy equations between other layers can be written in a similar fashion. Here $\alpha_{p}$ is the absorptivity of the panel, $G$ is the irradiance, $E e$ is the electrical energy output, and $h_{\text {panel-ted }}$ is the heat transfer coefficient between panel and tedlar layer. Similarly, other heat transfer coefficients between the layers are defined in Equations (3) and (4). Values of these are adopted as constant and are listed in Table 4 as thermal and optical properties of PV/T system. 
Table 4. Thermal and optical properties of PV/T system.

\begin{tabular}{cc}
\hline Properties & Values \\
\hline Heat transfer coefficient from Panel to tedlar & $150 \mathrm{~W} / \mathrm{m}^{2} \mathrm{~K}$ \\
Heat transfer coefficient from tedlar to tubing & $77 \mathrm{~W} / \mathrm{m}^{2} \mathrm{~K}$ \\
Heat transfer coefficient from tubing to nanofluid & $66 \mathrm{~W} / \mathrm{m}^{2} \mathrm{~K}$ \\
Absorptivity of PV module & 0.9 \\
Absorptivity of tedlar sheet & 0.5 \\
Emissivity of PV panel & 0.99 \\
Thermal conductivity of EVA & $0.311 \mathrm{~W} / \mathrm{m}^{-} \mathrm{K}$ \\
Thermal conductivity solar panel & $148 \mathrm{~W} / \mathrm{m}^{-} \mathrm{K}$ \\
Thermal conductivity of tedlar & $0.15 \mathrm{~W} / \mathrm{m}^{-} \mathrm{K}$ \\
Thermal conductivity of thermal paste & $1.9 \mathrm{~W} / \mathrm{m}^{-} \mathrm{K}$ \\
Thermal conductivity of tubes & $2700 \mathrm{~W} / \mathrm{m}^{-} \mathrm{K}$ \\
\hline
\end{tabular}

From the tedlar to serpentine tubing:

$$
-\left(\frac{k}{\rho C_{p}}\right)\left(\frac{\partial^{2} T}{\partial x^{2}}+\frac{\partial^{2} T}{\partial y^{2}}+\frac{\partial^{2} T}{\partial z^{2}}\right)=-h_{\text {penal-ted }}\left(T_{p}-T_{t d}\right)-h_{\text {ted-tubing }}\left(T_{\text {ted }}-T_{\text {tubing }}\right)
$$

From the serpentine tubing to nanofluid:

$$
-\left(\frac{k}{\rho C_{p}}\right)\left(\frac{\partial^{2} T}{\partial x^{2}}+\frac{\partial^{2} T}{\partial y^{2}}+\frac{\partial^{2} T}{\partial z^{2}}\right)=-h_{\text {ted-tubing }}\left(T_{\text {ted }}-T_{\text {tubing }}\right)-h_{\text {tubing-nf }}\left(T_{\text {tubing }}-T_{n f}\right)
$$

The conjugate heat transfer equation is used for flow in the collector with both conduction and convection shown in Equation (5). Finally, the mass and momentum equation laminar fluid flow are given by Equations (6)-(9).

$$
\begin{gathered}
\rho_{n f} C_{P n f}\left(u \frac{\partial T}{\partial x}+v \frac{\partial T}{\partial y}+w \frac{\partial T}{\partial z}\right)=K_{n f}\left(\frac{\partial^{2} T}{\partial x^{2}}+\frac{\partial^{2} T}{\partial y^{2}}+\frac{\partial^{2} T}{\partial z^{2}}\right) \\
\frac{\partial u}{\partial x}+\frac{\partial v}{\partial y}+\frac{\partial w}{\partial z}=0
\end{gathered}
$$

X-momentum:

$$
\rho_{n f}\left(u \frac{\partial u}{\partial x}+v \frac{\partial u}{\partial y}+w \frac{\partial u}{\partial z}\right)=\frac{-\partial P}{\partial x}+\mu_{n f}\left(\frac{\partial^{2} u}{\partial x^{2}}+\frac{\partial^{2} u}{\partial y^{2}}+\frac{\partial^{2} u}{\partial z^{2}}\right)
$$

Y-momentum:

$$
\rho_{n f}\left(u \frac{\partial v}{\partial x}+v \frac{\partial v}{\partial y}+w \frac{\partial v}{\partial z}\right)=\frac{-\partial P}{\partial y}+\mu_{n f}\left(\frac{\partial^{2} v}{\partial x^{2}}+\frac{\partial^{2} v}{\partial y^{2}}+\frac{\partial^{2} v}{\partial z^{2}}\right)
$$

Z-momentum:

$$
\rho_{n f}\left(u \frac{\partial w}{\partial x}+v \frac{\partial w}{\partial y}+w \frac{\partial w}{\partial z}\right)=\frac{-\partial P}{\partial z}+\mu_{n f}\left(\frac{\partial^{2} w}{\partial x^{2}}+\frac{\partial^{2} w}{\partial y^{2}}+\frac{\partial^{2} w}{\partial z^{2}}\right)
$$

The density $\rho_{n f}$ and heat capacitance, $C_{P n f}$ of nanofluid is assumed constant and their values were derived from empirical correlation available in archival literature [43] given below:

$$
\begin{gathered}
\rho_{n f}=(1-\phi) \rho_{b f}+\phi \rho_{s} \\
C p_{n f}=(1-\phi)\left(C_{P}\right)_{b f}+\phi\left(C_{P}\right)_{s}
\end{gathered}
$$


Energy balance is applied across the hybrid PV/T system given in Equation (12), which consists of irradiance coming from the sun, radiation from the panel surface, convection between PV/T system and ambient, thermal energy generated and the electrical power output.

$$
G-P_{e l}-P_{t h}-Q_{c o n v}^{\prime}-Q_{r a d}^{\prime}
$$

Convective and radiative heat transfer from PV/T system are given by Equations (13) and (14) as follows. The convective heat transfer and radiative heat transfer from panel are calculated on the basis of Newton's law of cooling and Stefan-Boltzmann law respectively.

$$
\begin{gathered}
-n \cdot(-k \nabla T)=h_{\text {total }}\left(T_{\text {surface }}-T_{\text {ambient }}\right) \\
-n \cdot(-k \nabla T)=\varepsilon \sigma\left(T_{\text {surface }}^{4}-T_{\text {sky }}^{4}\right)
\end{gathered}
$$

where $h_{\text {total }}$ is the total heat transfer coefficient evaluated as $h_{\text {total }}=\left(h_{\text {forced }}^{3}+h_{\text {natural }}^{3}\right)^{\frac{1}{3}}$. This includes the both effect natural convection and forced convection over the panel. Where forced and natural convection heat transfer coefficient [46] are calculated by Equations (15) and (16).

$$
\begin{gathered}
h_{\text {natural }}=1.78\left(T_{\text {amb }}+T_{\text {surface }}\right)^{\frac{1}{3}} \\
h_{\text {forced }}=2.8+3.0 V_{\text {wind }}
\end{gathered}
$$

Whereas the sky temperature is calculated using Swinbank relation [46] as $T_{\text {sky }}=0.037536 T_{\text {amb }}^{4}+$ $0.32 T_{a m b}$. In Equation (14) $\varepsilon$ is the emissivity of panel and $\sigma$ is the Stefan-Boltzmann constant.

The electrical power and thermal energy output are expressed by

$$
\begin{gathered}
P_{\text {el }}=V_{o c} * I_{s C} * F F \\
P_{\text {th }}=m C_{p}\left(T_{\text {out }}-T_{\text {in }}\right)
\end{gathered}
$$

Electrical and thermal efficiency are obtained by Equations (19) and (20), respectively

$$
\begin{aligned}
\eta_{e l} & =\frac{P_{e l}}{G * A_{c}} \\
\eta_{t h} & =\frac{P_{t h}}{G * A_{c}}
\end{aligned}
$$

\subsection{Boundary Conditions}

Appropriate boundary conditions were employed across the domain as per the physics of problem. Across the top and bottom layer of PV module the boundary condition applied is $-n \cdot q=h_{c}\left(T_{a m b}-T_{s}\right)$. Where $\mathbf{n}$ is the surface normal and $T_{a m b}$ and $T_{s}$ are the ambient temperature and surface temperature, respectively. For the fluid domain the inlet boundary condition is specified as velocity inlet along $x$-axis i.e., $\mathrm{u}=\mathrm{U}_{\mathrm{o}}, \mathrm{v}=0, \mathrm{w}=0$ and $\mathrm{T}=\mathrm{T}_{\mathrm{o}}$, for solid boundaries no-slip condition is used $(\mathrm{u}=\mathrm{v}=\mathrm{w}=0)$, however at the outlet zero pressure boundary condition is used $(p=0)$. For solid-fluid interface heat flux continuity at the interface is used $\left(\frac{\partial T_{s}}{\partial n}\right)_{f}=\frac{k_{s}}{k_{f}}\left(\frac{\partial T_{s}}{\partial n}\right)_{s^{\prime}}$ adiabatic boundary condition is employed for the side surfaces of the system. Moreover, the lowermost plate of the hybrid solar PV/T system remains insulated.

\subsection{Meshing and Grid Independence}

The PV/T module was meshed in COMSOL Multiphysics®using the built-in physics-controlled mesh sequence setting shown in Figure 4. It consists of tetrahedral and triangular mesh element at 
the sub-domain and at the boundary respectively. The number of mesh elements increase at each boundary so that the heat transfer and flow fields can be resolved accurately. For grid independence, simulation at $1000 \mathrm{~W} / \mathrm{m}^{2}$ and a mass flow rate of $0.05 \mathrm{~kg} / \mathrm{s}$ is performed using water as a coolant with different mesh size (from coarser to finer) shown in Table 5. It was observed that there was no further change in panel temperature and outlet fluid temperature values after mesh no. 5. Thus, mesh no. 5 is chosen for simulation purposes. As far as quality measures are concerned, we checked the orthogonality, skewness, and growth rate of the elements and found satisfactory values of 0.65 , 0.7 , and 1.5 respectively. These values given us good quality mesh and the dialog box in COMSOL appears which states the minimum element quality to be 0.3319 . If this value is $<10^{-4}$ the quality is extremely poor. Apart from this there is one more parameter termed as aspect ratio which is 0.3 , and it is a thumb rule in COMSOL if it is greater than 0.1 , it would not affect the quality of the solution, in this simulation mesh curvature factor is 0.3 and mesh curvature cut-off is 0.001 . In the boundary layer meshing, 8 layers with a stretching factor of 1.2 and scaling factor of 1 is used. The initial layer thickness is designated as $1 / 50$ of the size of element on that boundary. The meshing along the thickness and around the tubing is shown in Figure $5 \mathrm{a}, \mathrm{b}$. The maximum and minimum deviation in the panel temperature for the six different meshes is $2.3 \%$ and $0.002 \%$ respectively. Similarly, for outlet fluid temperature, it is $-2.94 \%$ and $-0.22 \%$. It was closely observed that, with consideration of mesh no. 6 , the computational cost increases with meagre accuracy increment. Therefore, mesh no. 5 was considered for all the simulations.

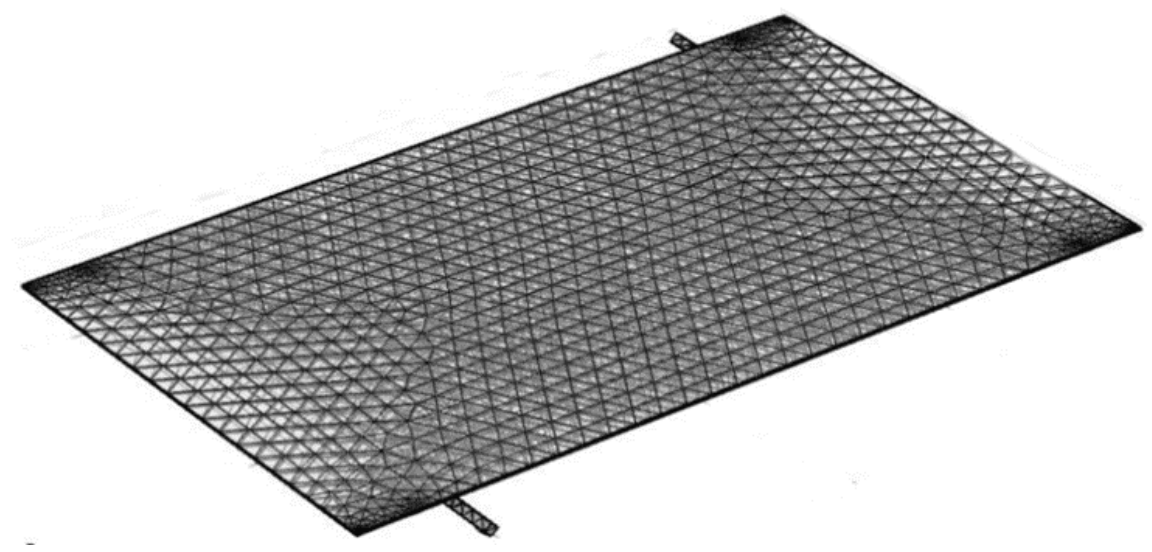

Figure 4. PV/T element with finite element meshing.

Table 5. Grid independence test.

\begin{tabular}{ccccccc}
\hline S.No. & $\begin{array}{c}\text { Mesh Size } \\
\text { (no. of } \\
\text { Elements) }\end{array}$ & $\begin{array}{c}\text { Panel } \\
\text { Temperature } \\
\left({ }^{\circ} \mathbf{C}\right)\end{array}$ & \% Deviation & $\begin{array}{c}\text { Outlet } \\
\text { Temperature } \\
\left({ }^{\circ} \mathbf{C}\right)\end{array}$ & \% Deviation & $\begin{array}{c}\text { Time of } \\
\text { Solution (s) }\end{array}$ \\
\hline 1 & $2.5 \times 10^{5}$ & 42.341 & - & 41.213 & - & 560 \\
2 & $4 \times 10^{5}$ & 43.872 & $1.2 \%$ & 40.751 & $-1.13 \%$ & 720 \\
3 & $6 \times 10^{5}$ & 44.003 & $0.29 \%$ & 40.254 & $-1.23 \%$ & 817 \\
4 & $8 \times 10^{5}$ & 44.118 & $0.26 \%$ & 39.104 & $-2.94 \%$ & 1115 \\
5 & $1.5 \times 10^{6}$ & 45.200 & $2.3 \%$ & 38.889 & $-0.55 \%$ & 1487 \\
6 & $3.5 \times 10^{6}$ & 45.201 & $0.002 \%$ & 38.801 & $-0.22 \%$ & 1815 \\
\hline
\end{tabular}




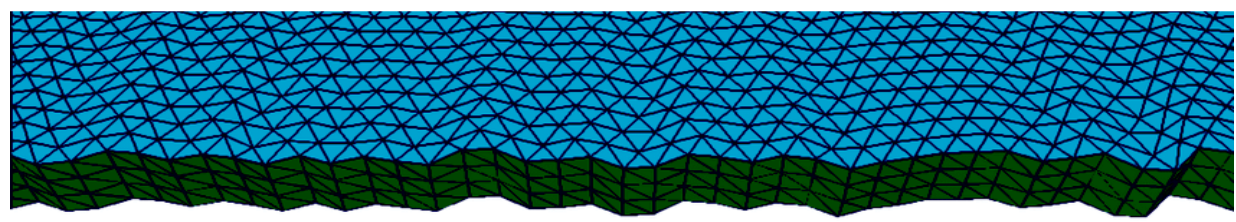

(a)

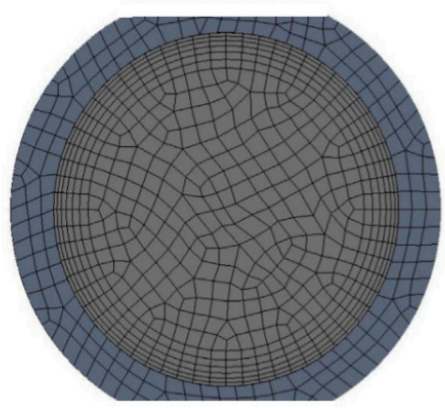

(b)

Figure 5. (a) Mesh along the thickness of panel. (b) Mesh inside and outside the tube.

\section{Results and Discussions}

\subsection{Morphology and Characterization}

Two-dimensional $\mathrm{Ti}_{3} \mathrm{C}_{2}$ was successfully synthesized from three-dimensional $\mathrm{MAX}\left(\mathrm{Ti}_{3} \mathrm{AlC}_{2}\right)$ phase which is evidenced by SEM micrographs presented in Figure 6a,b. The distinct self -staking layered structure of $\mathrm{Ti}_{3} \mathrm{C}_{2}$ which is clearly seen from SEM photographs is consistent with previous studies [57-59]. This layered structure is formed owing to the domino effect of van der Walls forces between two adjacent layers. Additionally, TEM images of multilayer flacks have a lateral size of up to 100 nanometers.

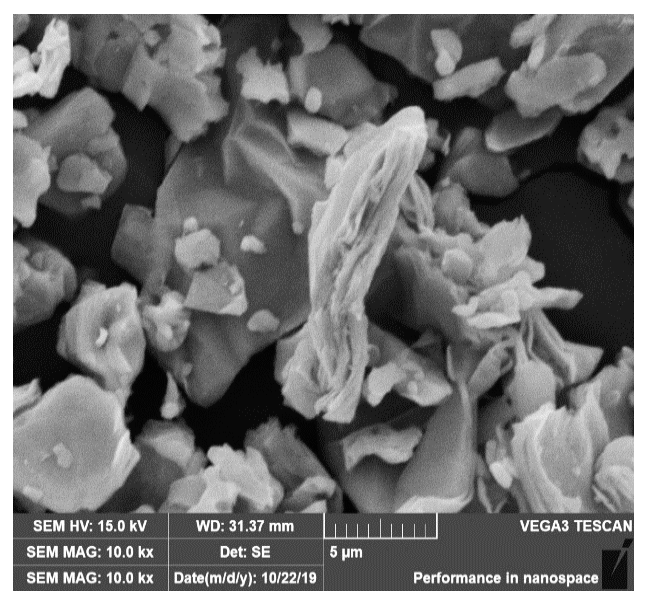

(a)

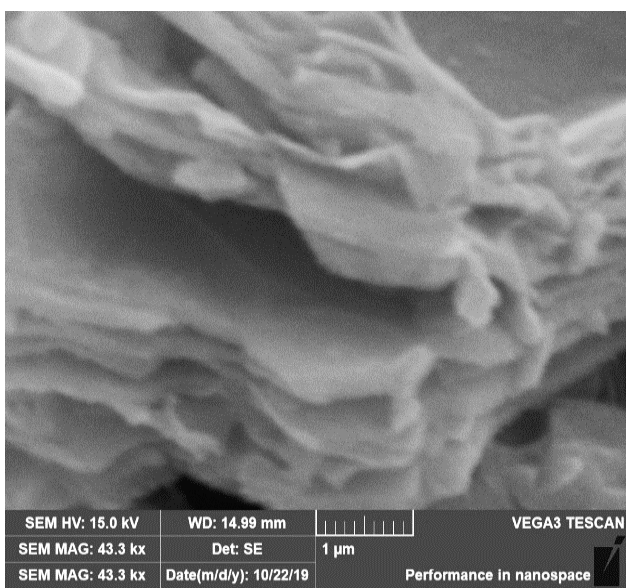

(b)

Figure 6. SEM micrographs of as synthesized $\mathrm{Ti}_{3} \mathrm{C}_{2}$ (MXene) (a) at $5 \mu \mathrm{m}$ magnification (b) at $1 \mu \mathrm{m}$ magnification.

The FTIR spectra of the formulated samples are presented in Figure 7. The broad peak appearing at wavelength $620 \mathrm{~cm}^{-1}$ is assigned to the chemically stable Ti-O bond, therefore, confirming the 
dispersion of $\mathrm{Ti}_{3} \mathrm{C}_{2}$ (MXene) in the IL aqueous solutions which is in good agreement with previous studies [60,61]. Additionally, a few more peaks appearing in the spectra of the sample solutions indicates the presence of stretching vibration bands of $\mathrm{O}-\mathrm{H}$ bond at $3337 \mathrm{~cm}^{-1}, \mathrm{C}=\mathrm{N}$ at $1643 \mathrm{~cm}^{-1}$, $\mathrm{C}=\mathrm{C}$ at $1579 \mathrm{~cm}^{-1}, \mathrm{C}-\mathrm{O}$ at $1176 \mathrm{~cm}^{-1}, \mathrm{C}-\mathrm{N}$ at $1037 \mathrm{~cm}^{-1}$ and bending vibration band $\mathrm{C}-\mathrm{H}$ at $816 \mathrm{~cm}^{-1}$. The assignment of these peaks strongly supports previous study in the literature for imidazolium-based ionic liquid [62]. The FTIR analysis implies that the dispersion of MXene into the IL solutions yields some functional groups which are stable, and no chemical reactions occur among the particles.

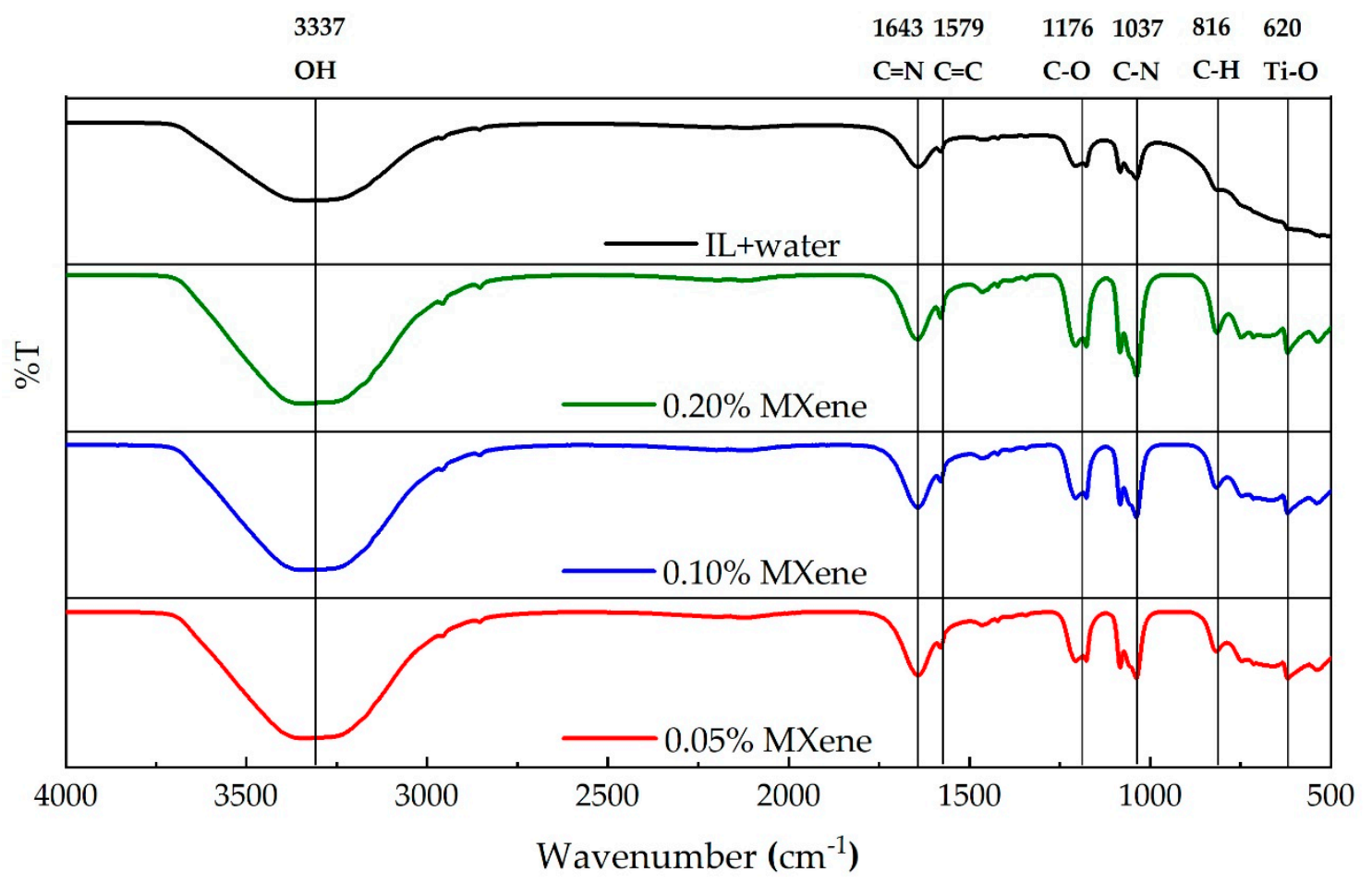

Figure 7. FTIR spectra of nanofluids at different concentrations.

Figure $8 \mathrm{a}, \mathrm{b}$ illustrates the UV-vis spectra of pure IL solution and $\mathrm{Ti}_{3} \mathrm{C}_{2}$ dispersed ionanofluids at different wavelengths. As shown in the figure, the absorbance peak appearing at wavelength of $291 \mathrm{~nm}$ increases substantially with the addition of $\mathrm{Ti}_{3} \mathrm{C}_{2}$ nanosheets, demonstrating that the optical absorption capability of the solution increases notably with the addition of two dimensional $\mathrm{Ti}_{3} \mathrm{C}_{2}$ nanosheet. Similar trends were observed from past studies with carbon-based 2D nanomaterials [34,63]. Moreover, the linear relationship between the nano additives concentration and absorbance justifies the Beer's law fairly. This phenomenon is attributed to the high absorption ability of carbon and carbon-based nanocomposites. It must be noted that higher absorption ability of a fluid provides better performance for energy storage system specially for solar energy storage system [64].

Stability is substantially related to electro-kinetic potential differences between the stationary layer attached solid nanoparticles and dispersion medium [65]. A nanofluids must be stable enough before taking it for application. A nanofluid without stability will not be applicable even though it exhibits outstanding thermophysical and optical properties. The stability of [MMIM][DMP]+water/Ti ${ }_{3} \mathrm{C}_{2}$ nanofluids were measured in terms of zeta $(\zeta)$ potential. Table 6 illustrates the values of $\zeta$ potential measured as a function of temperature. As shown from the table, the prepared ionanofluids exhibit good stability without adding any surfactants (a commonly practiced chemical treatment to improve the stability by promoting interactions among particles). This is due to the fact that, MXene is strongly hydrophilic in nature that have strong interactions with water solution [66]. Furthermore, IL [MMIM][DMP] is also hydrophilic which also contributed to improving stability [67]. On the other hand, $\zeta$ potential of the sample shows a trend to increase with increasing concentration from $0.05 \mathrm{wt} \%$ 
to $0.10 \mathrm{wt} \%$ of $\mathrm{Ti}_{3} \mathrm{C}_{2}$ nanosheets. The increase in $\zeta$ potential can be explained by the fact that with increasing concentration the surface area of $\mathrm{Ti}_{3} \mathrm{C}_{2}$ nanosheet also increases, which in turn absorbs negative ions in their surface, therefore, the potential difference between the $\mathrm{Ti}_{3} \mathrm{C}_{2}$ surface and IL solutions increases. However, further increase in $\mathrm{Ti}_{3} \mathrm{C}_{2}$ concentration causes a decline in the $\zeta$ potential. A possible explanation for this is that although the surface area of the nanoparticles is increased, correspondingly the attractive forces between them are also increased causing their zeta potential to deteriorate. Similar trends were noticed in previous findings [68,69]. The effect of temperature on zeta potential value is also significant. For each case the $\zeta$ potential value increases significantly with increasing temperature which exhibits more stable structure with liquid particles. This is possibly due to the reduction of intermolecular forces between $\mathrm{Ti}_{3} \mathrm{C}_{2}$ particles as the Brownian motion increased with the temperature. Similar observations were also noticed for 2D graphene and carbon-based nanosheets in water solution [70]. As the $\zeta$ potential value increases with temperature, it clearly indicates the dispersion stability is improved at higher temperatures, which can be an advantage for better performance at higher temperatures. Taken together, these results suggest that a critical concentration is required to obtain the optimum value of the $\zeta$ potential which assures better stability of the suspension solution.
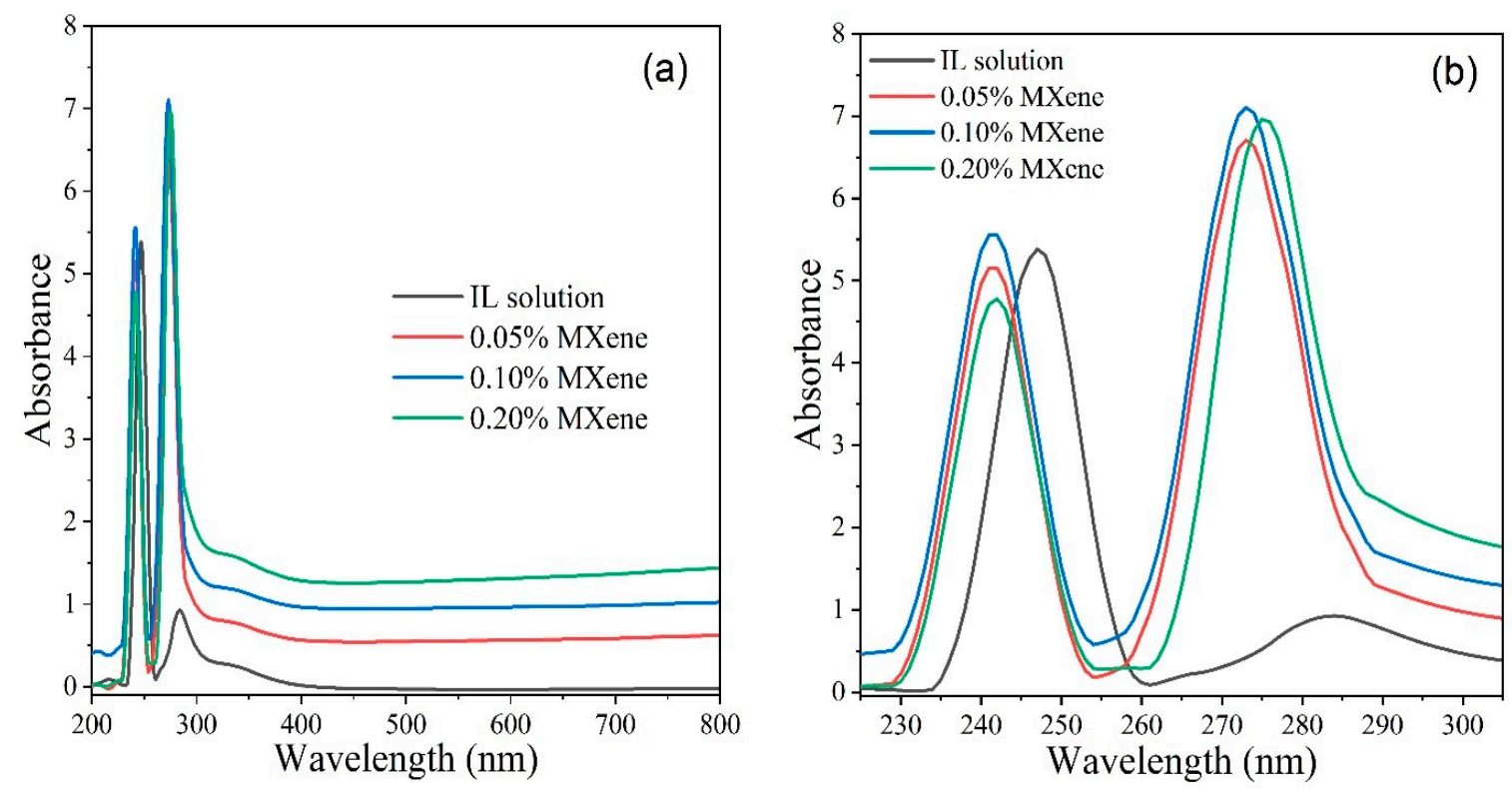

Figure 8. (a) UV-vis spectra of pure IL solution and nanofluids, (b) magnified view from $225 \mathrm{~nm}$ to $305 \mathrm{~nm}$ wavelength.

Table 6. $\zeta$-potential of ionanofluids different weight concentration $\mathrm{Ti}_{3} \mathrm{C}_{2}$.

\begin{tabular}{ccccccc}
\hline & \multicolumn{7}{c}{ Zeta Potential (mV) } \\
\cline { 2 - 7 } Concentration & $\mathbf{2 5}{ }^{\circ} \mathbf{C}$ & $\begin{array}{c}\text { Uncertainty } \\
\mathbf{( \% )}\end{array}$ & $\mathbf{4 5}{ }^{\circ} \mathbf{C}$ & $\begin{array}{c}\text { Uncertainty } \\
\mathbf{( \% )}\end{array}$ & $\mathbf{6 0}{ }^{\circ} \mathbf{C}$ & $\begin{array}{c}\text { Uncertainty } \\
\mathbf{( \% )}\end{array}$ \\
\hline 0.05 & -18.33 & $<5$ & -29.52 & $<5$ & -38.68 & $<5$ \\
0.10 & -19.16 & $<5$ & -34.64 & $<5$ & -39.54 & $<5$ \\
0.20 & -17.88 & $<5$ & -32.15 & $<5$ & -35.35 & $<5$ \\
\hline
\end{tabular}

\subsection{Thermophysical Properties}

\subsubsection{Thermal Conductivity}

The thermal conductivities of the IL+ water solution and [MMIM][DMP]+water/ $/ \mathrm{Ti}_{3} \mathrm{C}_{2}$ ionanofluids was determined at four distinct temperatures, ranging from $25^{\circ} \mathrm{C}$ to $60^{\circ} \mathrm{C}$. The obtained values of 
each sample are depicted in Figure 9a and thermal conductivity enhancement of the ionanofluids $\left(\mathrm{K}_{\mathrm{nf}} / \mathrm{K}_{\mathrm{IL}}-1\right)$ are shown in Figure $9 \mathrm{~b}$. As shown in Figure $9 \mathrm{a}$, thermal conductivity of IL aqueous solution at $25^{\circ} \mathrm{C}$ is $0.468 \mathrm{~W} / \mathrm{m} . \mathrm{K}$ and rises up to $0.597 \mathrm{~W} / \mathrm{m} . \mathrm{K}$ as the temperature reaches $60{ }^{\circ} \mathrm{C}$ which completely agrees with the previous study at the same volume fraction and temperature of IL [71]. The trend of the thermal conductivity shows significant improvement with the addition of $\mathrm{Ti}_{3} \mathrm{C}_{2}$ nanosheets are into [MMIM][DMP]+water solution and continues improving as the loading of $\mathrm{Ti}_{3} \mathrm{C}_{2}$ nanosheets are increases. High surface area of nanoparticles, better heat transport properties, and good interaction with fluid nanoparticles are the primary facotrs that improve thermal conductivity. In addition, thermal conductivity of all samples increases remarkably with increasing temperature as a consequence of intensified Brownian motion of liquid molecules. As seen from Figure $9 \mathrm{~b}$, a maximum $47 \%$ enhancement in thermal conductivity occurs at $35{ }^{\circ} \mathrm{C}$ for $0.20 \%$ loading of $\mathrm{Ti}_{3} \mathrm{C}_{2}$ nanosheets, which is higher compared to $4.95 \%$ with graphene nanosheet/water nanofluids [72], $22.9 \%$ with graphene/[HMIM] $\left[\mathrm{BF}_{4}\right]$ ionanofluid [73], and $2 \%$ with GNP/EG nanofluids [74]. As higher thermal conductivity of HTFs offers higher thermal efficiency, it can be asserted that MXene dispersed nanofluid can be employed as novel HTF for solar PV/T systems.
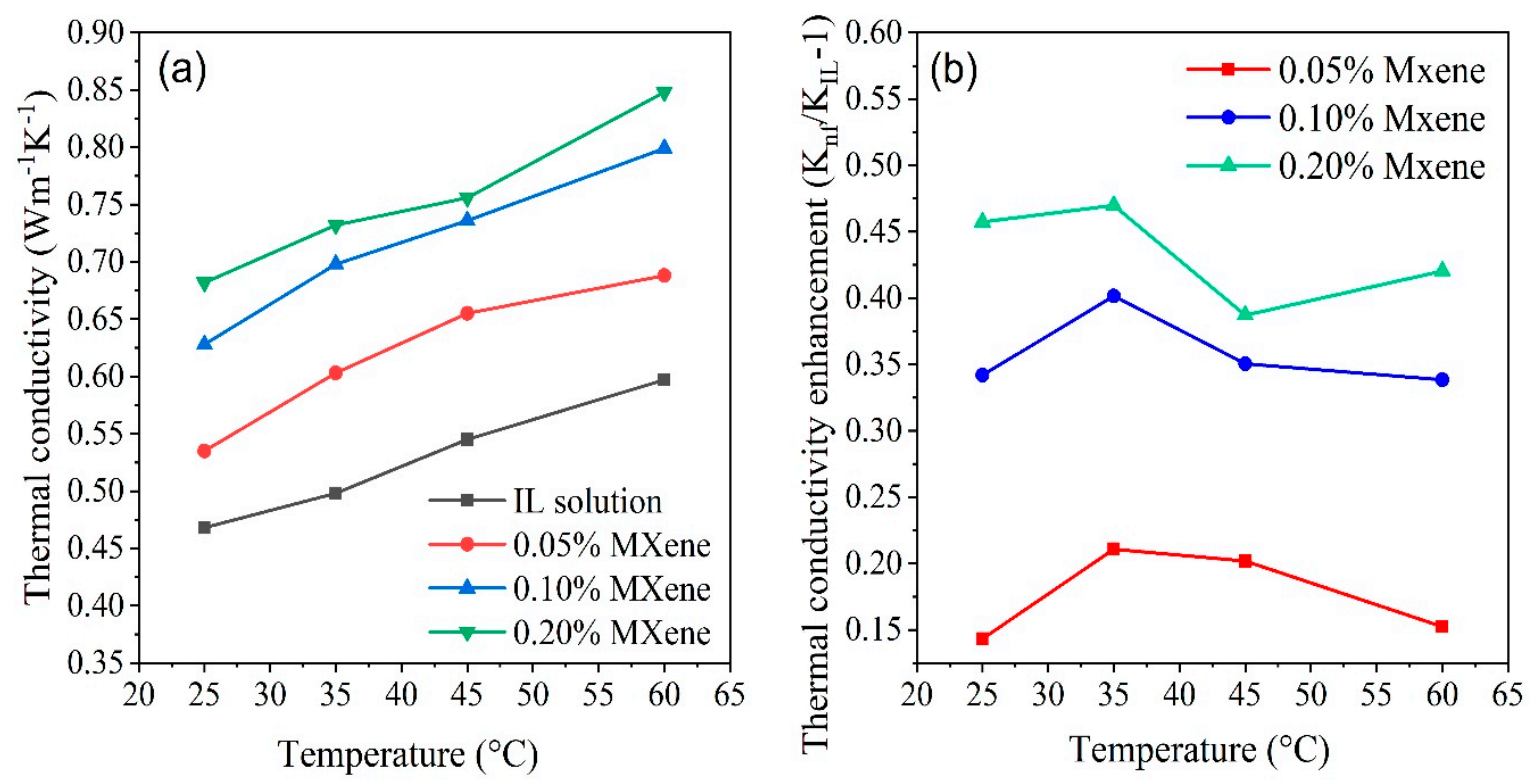

Figure 9. (a) Experimental values of thermal conductivity at different concentrations of $\mathrm{Ti}_{3} \mathrm{C}_{2}$ nanosheets for varying temperatures. (b) Thermal conductivity enhancement ratio at different temperatures with respect to IL+ water solution.

\subsubsection{Specific Heat}

The specific heat of [MMIM][DMP]+water solution and [MMIM][DMP]+water/ $/ \mathrm{Ti}_{3} \mathrm{C}_{2}$ nanofluids for $0.05,0.10$, and $0.20 \mathrm{wt} \%$ of nanoparticle loading were measured in the temperature ranges from $26^{\circ} \mathrm{C}$ to $60^{\circ} \mathrm{C}$. Figure 10 elucidates the variation of specific heat for base fluid and ionanofluids as a function of temperature. According to the trend lines, it is obvious that the dispersion of $\mathrm{Ti}_{3} \mathrm{C}_{2}$ nanosheets into the IL+ water solution causes the increase of specific heat of the solution which could be ascribed to the high specific surface energy of $2 \mathrm{D} \mathrm{Ti}_{3} \mathrm{C}_{2}$ nanosheets. Similar trends were noticed from previous studies for trinary carbonate/CNT nanofluids [75], molten salt/ $/ \mathrm{SiO}_{2}$ [76]. Furthermore, the specific heat is found to rise with increasing temperature for each sample. In other words, as the fluid heats up, the kinetic energy increases causing the fluid molecules to reach vibration state which enhances energy storage ability. Previous studies $[36,77]$ showed similar trends which are consistent with the present study and mostly for imidazolium-based ionanofluids [78]. The specific heat of pure [MMIM][DMP]+water solution rises from 2.141 to $2.222 \mathrm{~J} / \mathrm{g} . \mathrm{K}$ with increasing temperature from $26^{\circ} \mathrm{C}$ to $60^{\circ} \mathrm{C}$ while for $0.05,0.10$, and $0.20 \mathrm{wt} \%$ of $\mathrm{Ti}_{3} \mathrm{C}_{2}$ ionanofluids, specific heat is noticed to increase 
linearly from 2.271 to $2.344 \mathrm{~J} / \mathrm{g} . \mathrm{K}, 2.315$ to $2.397 \mathrm{~J} / \mathrm{g} . \mathrm{K}$, and 2.399 to 2.537 , J/g.K respectively for the same temperature enhancement. It must be noted that enhanced specific heat would result in a better outcome for solar thermal application, especially for energy storage systems.

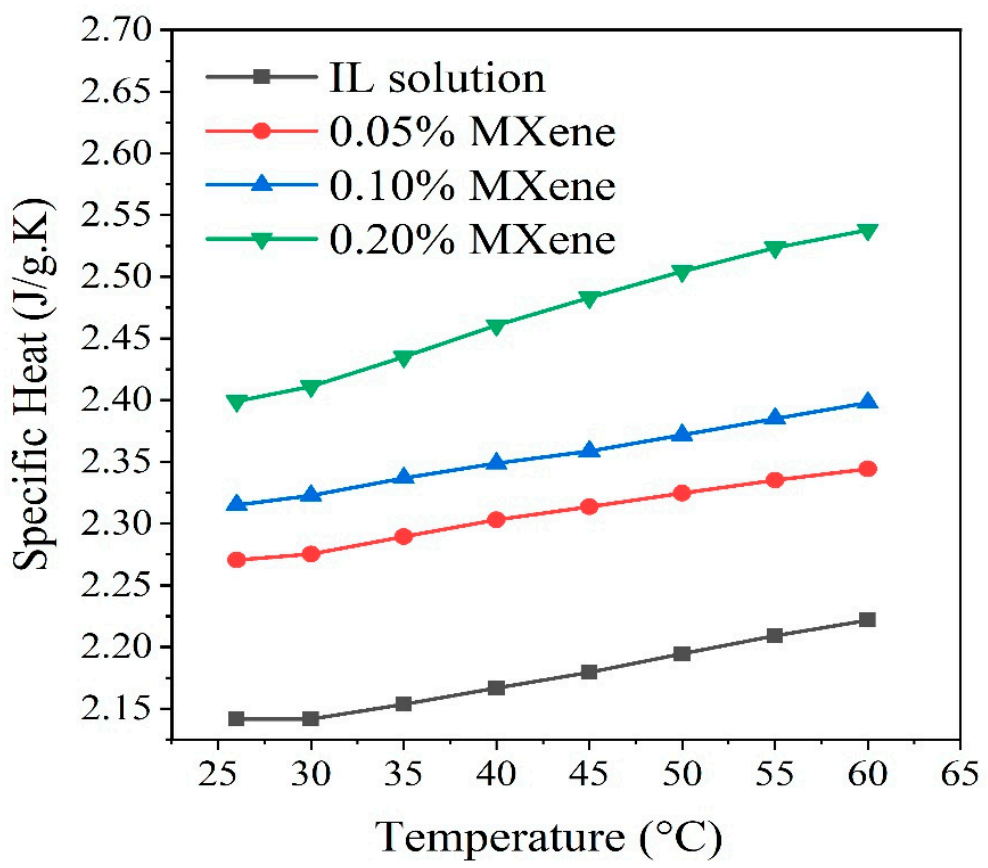

Figure 10. Specific heat capacity of IL aqueous solution and ionanofluids with various concentrations of $\mathrm{Ti}_{3} \mathrm{C}_{2}$.

\subsubsection{Viscosity}

Figure 11 illustrates the variation of dynamic viscosity of pure IL+water solutions and its nanofluids for different concentrations of $\mathrm{Ti}_{3} \mathrm{C}_{2}$ nanosheet in the temperature range from $25^{\circ} \mathrm{C}$ to $60{ }^{\circ} \mathrm{C}$. The viscosity of the pure IL+ water is lower than that of pure IL as less viscous water is added to IL [79]. It is obvious from the graph that the dynamic viscosity of the IL+ water solution increases from $2.694 \mathrm{mPa}$.s to $2.986 \mathrm{mPa}$.s when $\mathrm{Ti}_{3} \mathrm{C}_{2}$ nanosheets are added by $0.05 \mathrm{wt} \%$ while for $0.10 \mathrm{wt} \%$ and $0.20 \mathrm{wt} \%$ nanofluids, the viscosity further increases to $3.011 \mathrm{mPa}$.s and $3.066 \mathrm{mPa} . \mathrm{s}$ respectively. On the contrary, viscosity is noticed to decrease significantly as the temperature rises which complies with previous results $[80,81]$. The increase in viscosity of nanofluids attributes to the increasing shear stress with addition of $\mathrm{Ti}_{3} \mathrm{C}_{2}$ nanosheets into the IL+ water solutions. In other words, increasing the temperature weakens the intermolecular forces between the $\mathrm{Ti}_{3} \mathrm{C}_{2}$ particles and the solution itself. Hence, viscosity decreases as the temperature rises. However, lower viscosity is one of the major considerations for the application of HTF as higher viscosity increases pressure drop, therefore, it requires higher pumping power. In the current study, the increase in viscosity is almost negligible with increasing $\mathrm{Ti}_{3} \mathrm{C}_{2}$ nanosheet loading. Therefore, this conspicuous result emphasizes the reliability of using nanofluids in solar PV/T systems as a novel HTF. 


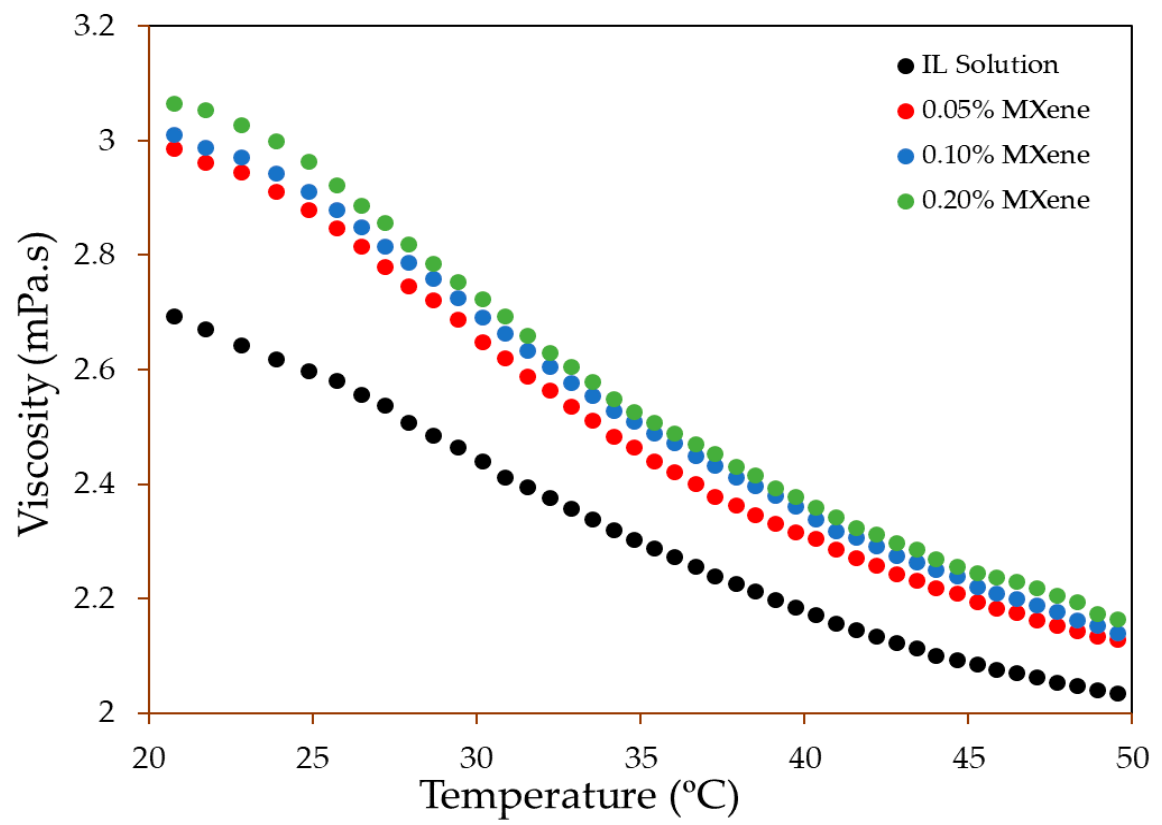

Figure 11. Dynamic viscosity of IL aqueous solution and ionanofluids with various concentration of $\mathrm{Ti}_{3} \mathrm{C}_{2}$.

\subsubsection{Density}

Density is also an important parameter for heat transfer systems as the pressure drop and pumping power significantly depend on density of the working fluids. Figure 12 illustrates the experimental density variation of the IL solution and ionanofluid at concentrations of $0.05,0.10$, and $0.20 \mathrm{wt} \% \mathrm{of} \mathrm{Ti}_{3} \mathrm{C}_{2}$ nanosheets. The result indicates a small increment of density when $\mathrm{Ti}_{3} \mathrm{C}_{2}$ nanosheets are dispersed into the IL solution at different concentrations which attributes to the addition of a high-density nanocomposites into the base fluid. In addition, the density decreases with increasing temperature as the kinetic energy of the fluids improves. In this study, maximum density occurs for the concentration of $0.20 \mathrm{wt} \%$ of $\mathrm{Ti}_{3} \mathrm{C}_{2}$ as expected as it rises from $1.037 \mathrm{gm} / \mathrm{cm}^{3}$ to $1.053 \mathrm{gm} / \mathrm{cm}^{3}$ at $20{ }^{\circ} \mathrm{C}$. Since enhancement is lower than $2 \%$, its effect the performance of the solar PV/T system will be negligible.

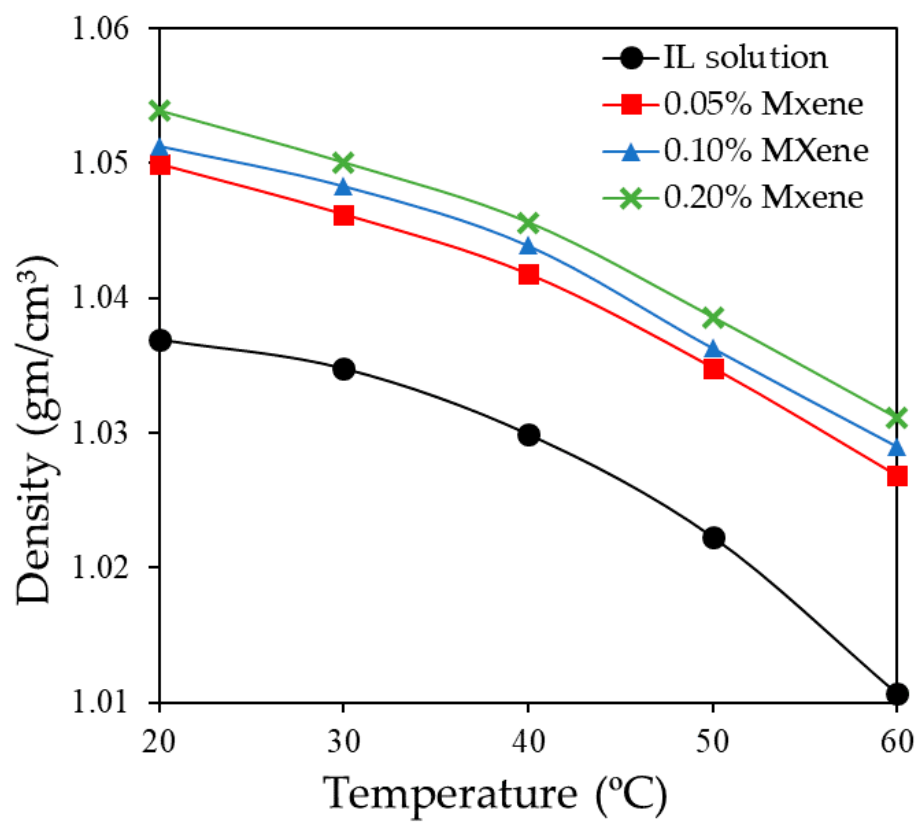

Figure 12. Density curve of IL+ water and IL + water $/ \mathrm{Ti}_{3} \mathrm{C}_{2}$. 


\subsubsection{Thermal Stability}

Thermal stability is another important parameter of thermal fluids since the applicability of thermal fluids greatly depended on their mass decomposition rate at working temperature [82]. The thermal stability is assessed by performing thermo gravimetric analysis (TGA) for each sample. Figure 13 illustrates the decomposition rate of the samples in terms of temperature. It is evident from the graph that all the samples are appreciably stable at up to $45^{\circ} \mathrm{C}$ while initial decomposition of water starts at $45^{\circ} \mathrm{C}$ for each sample. However, water contents are totally decomposed within $90^{\circ} \mathrm{C}$ to $120^{\circ} \mathrm{C}$ for different samples. It is obvious that the decomposition temperature of the nanofluids increases by dispersing $\mathrm{Ti}_{3} \mathrm{C}_{2}$ particles into the IL solution. This is attributed to the fact that some hydroxyl groups are introduced on the surface layers of the $\mathrm{Ti}_{3} \mathrm{C}_{2}$ particles that forms new functional groups containing high thermal stability. Furthermore, in the case of existing IL contents, no weight decomposes at up to $250{ }^{\circ} \mathrm{C}$ demonstrating all chemical bonds existing in the IL are strongly stable at up to $250^{\circ} \mathrm{C}$. Above $250^{\circ} \mathrm{C}$, all samples begin to decompose again and continue until all ionic liquids are fully decomposed nearly at $500{ }^{\circ} \mathrm{C}$. The TGA curves demonstrate that the existence of $\mathrm{Ti}_{3} \mathrm{C}_{2}$ nanosheets in IL solutions does not lead to significant alteration in the decomposition rate of the IL solutions.

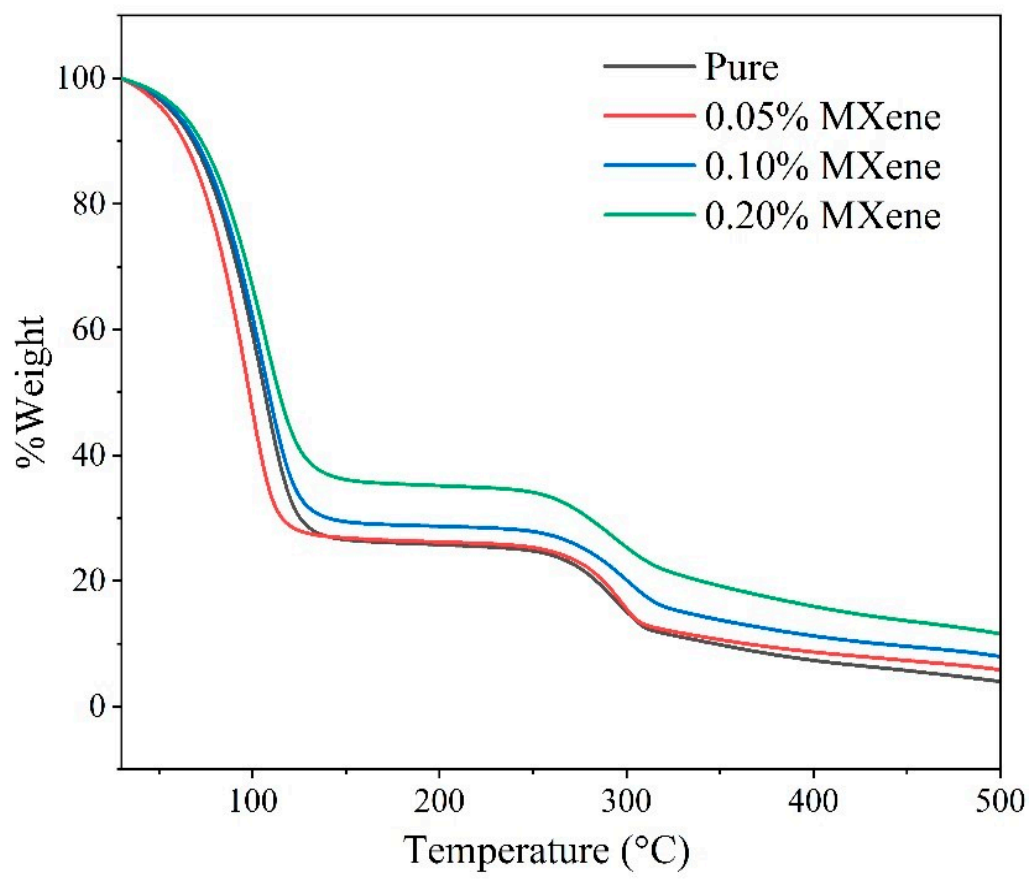

Figure 13. TGA curve of the IL+ water solution and ionanofluids at different concentrations of $\operatorname{Ti}_{3} \mathrm{C}_{2}$.

\subsection{Validation of Numerical Model}

A validation of model with previous results is depicted in Table 7. For validation purposes, a comparison is made with alumina-water nanofluid with numerical as well as experimental study of Sardarbadi et al. [83] and Lee et al. [84], respectively. It was observed that the results are in good agreement with previous results and shows an error of about $0.25 \%$ for panel temperature with numerical study and for electrical efficiency around $0.05 \%$ with experimental study. 
Table 7. Code validation of PV panel surface temperature and electrical efficiency.

\begin{tabular}{|c|c|c|c|}
\hline \multicolumn{2}{|c|}{ Panel temperature $\left({ }^{\circ} \mathrm{C}\right)$} & \multirow{2}{*}{ Percentage Error } & \multirow{2}{*}{ Remark } \\
\hline Present Research & Sardarabadi et al. [83] & & \\
\hline 56.35 & 56.21 & $0.25 \%$ & $\begin{array}{l}\text { At } 1000 \mathrm{~W} / \mathrm{m}^{2} \text { and at a flow rate } \\
\text { of } 0.025 \mathrm{~kg} / \mathrm{s} \text { (Numerical study of } \\
\text { [83]) }\end{array}$ \\
\hline \multicolumn{2}{|c|}{ Electrical efficiency } & & \\
\hline Present research & Lee et al. [84] & & \\
\hline 12.15 & 12.22 & $0.5 \%$ & $\begin{array}{c}\text { At } 1000 \mathrm{~W} / \mathrm{m}^{2} \text { and at a flow rate } \\
\text { of } 0.05 \mathrm{~kg} / \mathrm{s} \text { (Experimental study } \\
\text { of [84]) }\end{array}$ \\
\hline
\end{tabular}

\subsection{Performance of Solar PV/T System}

To maintain the PV module temperature in the permissible limit, three different coolants were examined in this study. All the simulations were carried out at $1000 \mathrm{~W} / \mathrm{m}^{2}$ with nanoparticle concentration of $0.2 \mathrm{wt} \%$. Figure 14 a shows comparison with water, water $/ \mathrm{Al}_{2} \mathrm{O}_{3}$, palm oil/MXene, and the newly developed IL+ water/MXene nanofluid to identify the effect on PV panel temperature during the daytime from 9:00 a.m. to 17:00 p.m. The simulation is scattered at at different times, alternatively we can say at different irradiance levels, and the average PV module temperature was noted for particular times or irradiances. Next, we plotted the curve for all times and joined them smoothly. It is not a transient situation. It was observed that MXene/IL+water solution shows a larger temperature drop across the PV panel, hence exhibiting better thermal performance. It is obvious from the figure that, at around 1:30 pm, the difference in the temperature between PV/T system using alumina nanofluid and the PV/T system using $\mathrm{IL}+$ water/MXene is $7.9^{\circ} \mathrm{C}$-i.e. IL+water/MXene nanofluids-showed a $15.19 \%$ increment in the heat removal performance relative to alumina based nanofluid and around $8.5 \%$ increment in the heat removal performance relative to palm oil/MXene nanofluid. This behavior is attributed to higher thermal conductivity of MXene nanoparticles as well as ionic liquid in comparison to palm oil as a base fluid.

Figure $14 \mathrm{~b}$ presented the comparison of electrical efficiency with varying mass flow rate for three coolants as mentioned above. The electrical efficiency is enhanced with increasing flow rate, for instance, using IL+water/MXene and palm oil/MXene nanofluids, efficiency increases from $12.2 \%$ to $13.95 \%$ and $12.2 \%$ to $13.15 \%$ respectively when mass flow rate increases from $0.01 \mathrm{~kg} / \mathrm{s}$ to $0.07 \mathrm{~kg} / \mathrm{s}$. Hence, by using palm oil based nanofluid in the hybrid PV/T system, a 7.8\% electrical efficiency improvement is achieved in comparison to alumina nanofluid at $0.07 \mathrm{~kg} / \mathrm{s}$ mass flow rate. Furthermore, by employing IL+water/MXene and at $0.07 \mathrm{~kg} / \mathrm{s}$ mass flow rate, an electrical efficiency improvement of $14.4 \%$ is achieved in comparison to alumina/water nanofluid.

In Figure 14c, thermal efficiency variation with mass flow rate is depicted for different coolants. It is evident from the figure that higher mass flow rate offers better thermal efficiency of the PV/T system irrespective of type of coolant. At a maximum mass flow rate of $0.07 \mathrm{~kg} / \mathrm{s}$, water shows $63.3 \%$ thermal efficiency, meanwhile alumina/water shows $71.18 \%$ thermal efficiency, MXene/palm oil shows $79.13 \%$ thermal efficiency, and IL+ water/MXene shows $81.15 \%$ thermal efficiency. It is clear from the results that IL solution based nanofluid is performing better than that of palm oil and water based nanofluids and has high heat transfer capability. IL+water/MXene has increased the thermal efficiency by $14 \%$ in comparison to alumina/water nanofluid. 


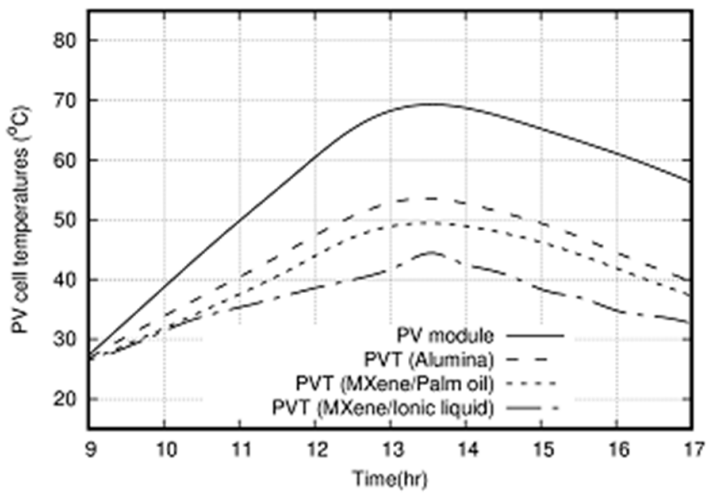

(a)

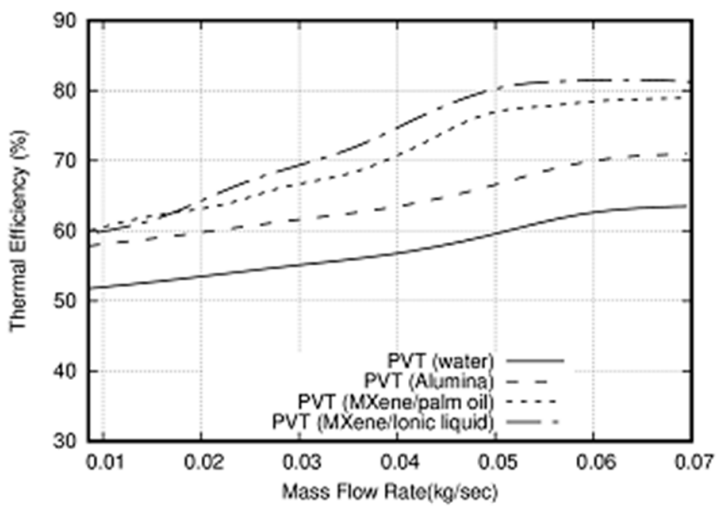

(c)

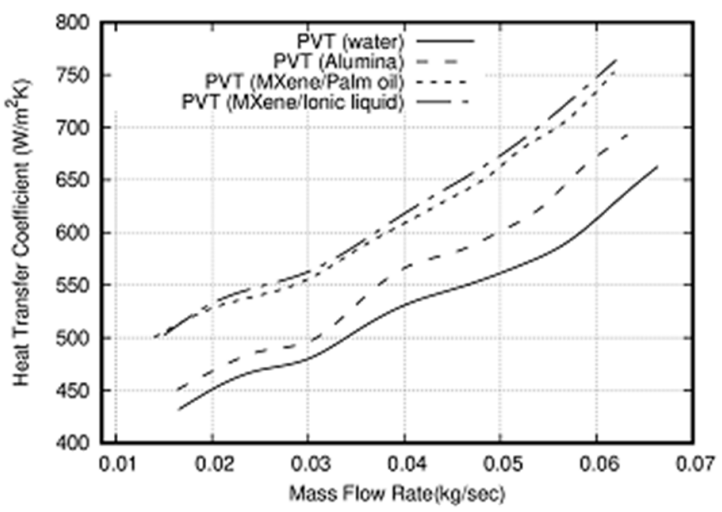

(e)

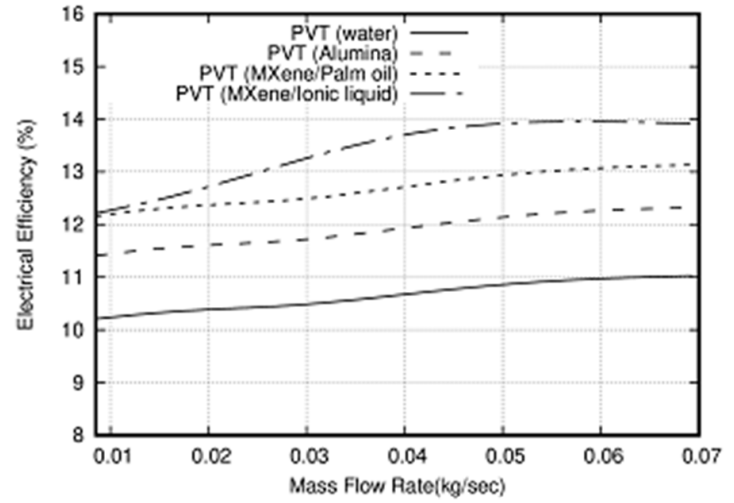

(b)

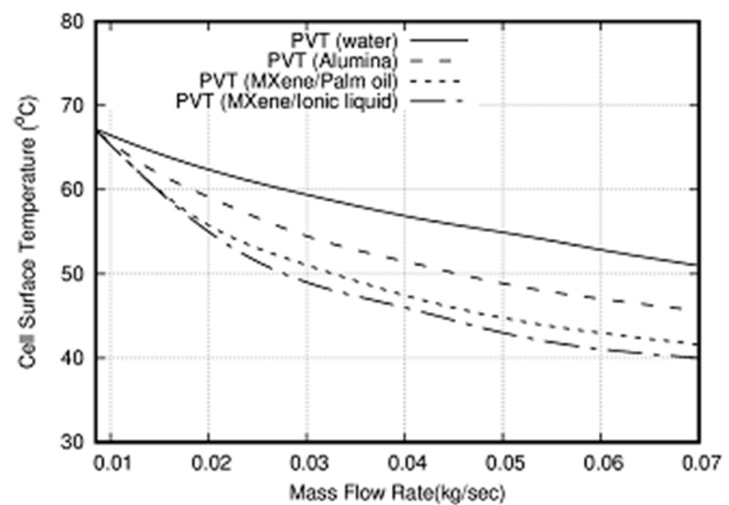

(d)

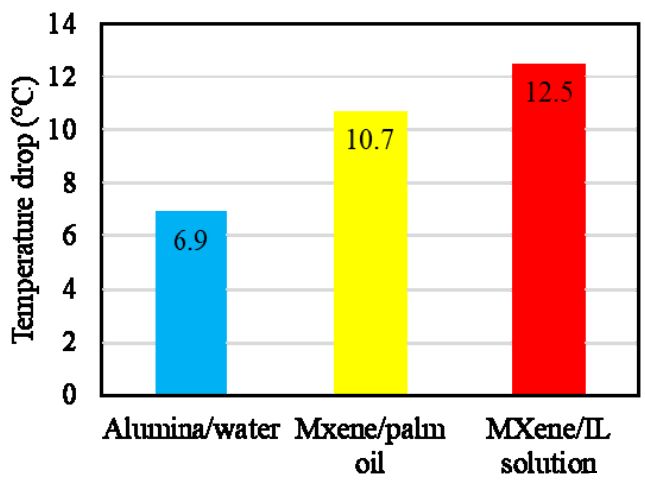

(f)

Figure 14. (a) Variation of PV panel temperature with time during a day for different types of coolant. (b) Electrical efficiency of PV/T system as a function of mass flow rate with different types of coolant.

(c) Thermal efficiency of PV/T system as a function of mass flow rate with different types of coolant.

(d) PV panel temperature as a function of mass flow rate using different types of coolant. (e) PV/T system heat transfer coefficient variation with mass flow rate using different types of coolant. (f) Drop in PV panel temperature by using different nanofluid types in comparison to a water-cooled system.

Figure $14 \mathrm{~d}$ presents the PV panel temperature with mass flow rate. It is obvious from the graph that the initial range of mass flow rate is less than $0.015 \mathrm{~kg} / \mathrm{s}$ and there is not much variation in the PV surface temperature. However, a decreasing trend is observed with significant variation thereafter. This is due to the increased convection rate from the module which decreases the panel surface temperature with increases in mass flow rate. At a maximum flow rate of $0.07 \mathrm{~kg} / \mathrm{s}$, the temperatures of the PV surface with alumina/water, palm oil/MXene, and IL+ water/MXene nanofluids are 45.07, 42.5 , and $40.5^{\circ} \mathrm{C}$ respectively. 
Finally, the heat transfer coefficient variation with mass flow rate is shown in Figure 14e. It was observed from the plot that heat transfer coefficient follows the increasing trend with mass flow rate irrespective of fluid used in the present study. Maximum percentage enhancement of $12.6 \%$ is achieved at $0.06 \mathrm{~kg} / \mathrm{s}$ for IL+ water/MXene relative to the $\mathrm{Al}_{2} \mathrm{O}_{3} /$ water nanofluid. Additionally, $2 \%$ enhancement is accomplished at $0.06 \mathrm{~kg} / \mathrm{s}$ for IL +water/MXene relative to palm oil/MXene nanofluid. Figure $14 \mathrm{f}$ shows the temperature drop using three types of nanofluid in PV/T systems which is relative to water coolant PV/T system. The maximum temperature drop of $12.5^{\circ} \mathrm{C}$ is achieved using IL+water/MXene as a coolant at maximum mass flow rate. It is clear from the results that IL+water/MXene is showing outstanding results in terms of thermal and electrical performance with its counterpart palm oil/MXene and alumina nanofluid.

\section{Conclusions}

In this present work, IL+ water nanofluids are formulated with novel $2 \mathrm{D} M$ Mene $\left(\mathrm{Ti}_{3} \mathrm{C}_{2}\right)$ nanosheet at three different concentrations $(0.05,0.10$, and $0.20 \mathrm{wt} \%)$ and their thermophysical properties (thermal conductivity, viscosity specific heat, density, and TGA) and optical properties (SEM, FTIR, UV-vis) are measured. On the basis of their optical and thermophysical properties, authors were highly motivated to apply this synthesized nanofluids in solar cooling system. As a consequence, a simulation-based application is performed with synthesized ionanofluid along with two other nanofluids (water/alumina, olein palm oil/MXene) in a hybrid solar PV/T system to compare their thermal performances. The findings of the investigation can be concluded as follows:

- $\quad$ The 2D MXene were successfully synthesized from 3D MAX phase and SEM analyses were performed to inspect the morphology of MXene before formulating ionanofluids.

- The formulated ionanofluids showed good stability without adding any surfactants or chemical treatment. Optical property measurement also showed a significant improvement in absorbance (UV-vis analysis) capability which may be considered a promising aspect of solar energy storage systems. The FTIR analyses also showed that the MXene particles were well dispersed into the solution and they were chemically stable.

- Superior results were also obtained for thermophysical properties as the thermal conductivity enhancements are significant at each concentration of MXene; however, a maximum of $47 \%$ enhancement is noticed at $0.2 \mathrm{wt} \%$. In addition, thermal conductivity increases substantially as the temperature rises from $20^{\circ} \mathrm{C}$ to $60{ }^{\circ} \mathrm{C}$.

- Interestingly, viscosity is found to be decreased by adding MXene nanosheets which might be attributed to their self-lubricating property. Specific heat increases with both increasing temperature and concentration while density is found to increase with concentration but decrease as temperature increases. TGA analysis also confirms that no significant decomposition occurs up to $60{ }^{\circ} \mathrm{C}$ within the samples.

- A simulation-based study has been conducted with IL+ water/MXene in a PV/T system along with two other nanofluids (water/alumina and palm oil/MXene) to assess the performance. IL+ water/MXene nanofluid with 20 wt \% concentrations exhibits highest electrical efficiency, overall thermal efficiency, and heat transfer coefficient in comparison with water, $\mathrm{Al}_{3} \mathrm{O}_{3} /$ water, and palm oil/MXene. Thermal efficiency of the considered PV/T system increases from 12.2 to $13.95 \%$ as flow rate increases from 0.01 to $0.07 \mathrm{~kg} / \mathrm{s}$ with IL+ water/MXene. Moreover, thermal efficiency is also increased by $81.15 \%$ while, heat transfer coefficient is also increased by $12.6 \%$ and $2 \%$ for IL+ water/MXene compared to water/alumina and palm oil/MXene.

Author Contributions: L.D.: Conceptions of work, research, draft preparing, writing. K.H.: Research, draft editing, analyzing, R.S.: writing-directing, editing, and reviewing. N.A., S.M.Y., and F.R.: simulation and analysis. All authors have read and agreed to the published version of the manuscript.

Funding: This research was funded by Sunway University, grant number- STR-RCTRRCNMET-001-2019 and APC was funded by Yayasan Universiti Teknologi PETRONAS, Grant number- 015LC0-118. 
Acknowledgments: The authors gratefully acknowledge Sunway University and Universiti Teknologi Petronas, Malaysia and Sunway University, Malaysia for mutual research collaboration. Deepest appreciation also goes to RCNMET, Sunway University for financial support (project no. STR-RCTRRCNMET-001-2019).

Conflicts of Interest: The authors declare no conflict of interest.

\section{Nomenclature}

\begin{tabular}{|c|c|c|c|}
\hline & Nomenclature & $\sigma$ & Stefan Boltzmann Constant, $\mathrm{W} /\left(\mathrm{m}^{2} \cdot \mathrm{K}^{4}\right)$ \\
\hline$A_{c}$ & area of collector $\left(\mathrm{m}^{2}\right)$ & Subscripts & \\
\hline$c_{p}$ & Specific heat $(\mathrm{J} / \mathrm{K})$ & $a m b$ & ambient \\
\hline$F F$ & field factor & el & electrical \\
\hline G & solar radiation intensity $\left(\mathrm{W} / \mathrm{m}^{2}\right)$ & $b f$ & base fluid \\
\hline$H$ & $\begin{array}{l}\text { convective heat transfer coefficient } \\
\left(\mathrm{W} / \mathrm{m}^{2} . \mathrm{K}\right)\end{array}$ & in & inlet \\
\hline$I_{s c}$ & short circuit current $(A)$ & out & outlet \\
\hline$k_{n f}$ & $\begin{array}{l}\text { thermal conductivity of nanofluid } \\
(\mathrm{W} / \mathrm{m} . \mathrm{K})\end{array}$ & $s$ & solid particle \\
\hline$k_{b f}$ & $\begin{array}{l}\text { thermal conductivity of base fluid } \\
(\mathrm{W} / \mathrm{m} . \mathrm{K})\end{array}$ & th & thermal \\
\hline$k_{s}$ & $\begin{array}{l}\text { thermal conductivity of } \\
\text { nanoparticle }(\mathrm{W} / \mathrm{m} \cdot \mathrm{K})\end{array}$ & $n f$ & Nanofluids \\
\hline$Q^{\prime}$ conv & heat transfer due to convection (W) & Abbreviations & \\
\hline$P_{t h}$ & thermal power output (W) & FTIR & Fourier-transform infrared spectroscopy \\
\hline$P_{e l}$ & electrical power output $(W)$ & NMR & nuclear magnetic resonance \\
\hline$Q^{\prime}$ rad & heat loss due to radiation $(\mathrm{W})$ & IC & ion chromatographic \\
\hline$T$ & temperature $(\mathrm{K})$ & KF & Karl Fischer \\
\hline$V_{o c}$ & open circuit voltage $(\mathrm{V})$ & IL & ionic liquid \\
\hline \multirow[t]{2}{*}{ Greeks } & & HPLC & $\begin{array}{l}\text { high performance liquid } \\
\text { chromatography }\end{array}$ \\
\hline & & TGA & thermogravimetric analysis \\
\hline$\zeta$ & zeta potential, $\mathrm{mV}$ & SEM & scanning electron microscopy \\
\hline$\Phi$ & nanoparticle weight fraction & $\mathrm{PV} / \mathrm{T}$ & photovoltaic thermal \\
\hline$\rho$ & density, $\mathrm{kg} / \mathrm{m}^{3}$ & SEM & scanning electron microscopy \\
\hline$\eta$ & efficiency & UV-vis & ultraviolet-visible spectroscopy \\
\hline$\varepsilon$ & emissivity & UDF & user defined function \\
\hline
\end{tabular}

\section{References}

1. IEA. World Energy Outlook 2019. 2019. Available online: https://www.iea.org/reports/world-energy-outlook2019 (accessed on 26 February 2020).

2. Krishna, Y.; Faizal, M.; Saidur, R.; Ng, K.C.; Aslfattahi, N. State-of-the-art heat transfer fluids for parabolic trough collector. Int. J. Heat Mass Transf. 2020, 152, 119541. [CrossRef]

3. Aslfattahi, N.; Saidur, R.; Sidik, N.A.C.; Sabri, M.F.M.; Zahir, M.H. Experimental Assessment of a Novel Eutectic Binary Molten Salt-based Hexagonal Boron Nitride Nanocomposite as a Promising PCM with Enhanced Specific Heat Capacity. J. Adv. Res. Fluid Mech. Therm. Sci. 2020, 73-85. [CrossRef]

4. Moghimi Ardekani, M. Optical Thermal and Economic Optimisation of a Linear Fresnel Collector; University of Pretoria: Pretoria, South Africa, 2017.

5. Yang, M.; Wang, S.; Zhu, Y.; Taylor, R.A.; Moghimi, M.; Wang, Y.J.E. Thermal Stability and Performance Testing of Oil-based CuO Nanofluids for Solar Thermal Applications. Energies 2020, 13, 876. [CrossRef]

6. Thirugnanasambandam, M.; Iniyan, S.; Goic, R. A review of solar thermal technologies. Renew. Sustain. Energy Rev. 2010, 14, 312-322. [CrossRef]

7. Borode, A.; Ahmed, N.; Olubambi, P. A review of solar collectors using carbon-based nanofluids. J. Clean. Prod. 2019, 241, 118311. [CrossRef]

8. Hjerrild, N.E.; Mesgari, S.; Crisostomo, F.; Scott, J.A.; Amal, R.; Taylor, R.A. Hybrid PV/T enhancement using selectively absorbing $\mathrm{Ag}-\mathrm{SiO}_{2}$ /carbon nanofluids. Sol. Energy Mater. Sol. Cells 2016, 147, 281-287. [CrossRef] 
9. Aguilar, T.; Sani, E.; Mercatelli, L.; Carrillo-Berdugo, I.; Torres, E.; Navas, J. Exfoliated graphene oxide-based nanofluids with enhanced thermal and optical properties for solar collectors in concentrating solar power. J. Mol. Liq. 2020, 306, 112862. [CrossRef]

10. Sadeghzadeh, M.; Maddah, H.; Ahmadi, M.H.; Khadang, A.; Ghazvini, M.; Mosavi, A.; Nabipour, N. Prediction of Thermo-Physical Properties of $\mathrm{TiO}_{2}-\mathrm{Al}_{2} \mathrm{O}_{3} /$ Water Nanoparticles by Using Artificial Neural Network. Nanomaterials 2020, 10, 697. [CrossRef]

11. Abdelrazik, A.; Tan, K.; Aslfattahi, N.; Arifutzzaman, A.; Saidur, R.; Al-Sulaiman, F.J.S.E. Optical, stability and energy performance of water-based MXene nanofluids in hybrid PV/thermal solar systems. Sol. Energy 2020, 204, 32-47. [CrossRef]

12. Zhu, D.; Wang, L.; Yu, W.; Xie, H. Intriguingly high thermal conductivity increment for CuO nanowires contained nanofluids with low viscosity. Sci. Rep. 2018, 8, 5282. [CrossRef] [PubMed]

13. Li, X.; Zeng, G.; Lei, X. The stability, optical properties and solar-thermal conversion performance of SiC-MWCNTs hybrid nanofluids for the direct absorption solar collector (DASC) application. Sol. Energy Mater. Sol. Cells 2019, 206, 110323. [CrossRef]

14. Sang, L.; Ai, W.; Wu, Y.; Ma, C. $\mathrm{SiO}_{2}$-ternary carbonate nanofluids prepared by mechanical mixing at high temperature: Enhanced specific heat capacity and thermal conductivity. Sol. Energy Mater. Sol. Cells 2019, 203, 110193. [CrossRef]

15. Bakthavatchalam, B.; Habib, K.; Saidur, R.; Saha, B.B.; Irshad, K. Comprehensive study on nanofluid and ionanofluid for heat transfer enhancement: A review on current and future perspective. J. Mol. Liq. 2020, 305, 112787. [CrossRef]

16. Aslfattahi, N.; Samylingam, L.; Abdelrazik, A.; Arifutzzaman, A.; Saidur, R.J.S.E.M.; Cells, S. MXene based new class of silicone oil nanofluids for the performance improvement of concentrated photovoltaic thermal collector. Sol. Energy Mater. Sol. Cells 2020, 211, 110526. [CrossRef]

17. Choi, S.U.; Eastman, J.A. Enhancing Thermal Conductivity of Fluids with Nanoparticles; Argonne National Lab.: Lemont, IL, USA, 1995.

18. Saidur, R.; Leong, K.Y.; Mohammed, H.A. A review on applications and challenges of nanofluids. Renew. Sustain. Energy Rev. 2011, 15, 1646-1668. [CrossRef]

19. Iranmanesh, S.; Ong, H.C.; Ang, B.C.; Sadeghinezhad, E.; Esmaeilzadeh, A.; Mehrali, M. Thermal performance enhancement of an evacuated tube solar collector using graphene nanoplatelets nanofluid. J. Clean. Prod. 2017, 162, 121-129. [CrossRef]

20. Amani, M.; Amani, P.; Mahian, O.; Estellé, P. Multi-objective optimization of thermophysical properties of eco-friendly organic nanofluids. J. Clean. Prod. 2017, 166, 350-359. [CrossRef]

21. Sarkar, J. A critical review on convective heat transfer correlations of nanofluids. Renew. Sustain. Energy Rev. 2011, 15, 3271-3277. [CrossRef]

22. Wang, X.Q.; Mujumdar, A.S. Heat transfer characteristics of nanofluids: A review. Int. J. Therm. Sci. 2007, 46, 1-19. [CrossRef]

23. Ahmadi, M.H.; Mirlohi, A.; Nazari, M.A.; Ghasempour, R. A review of thermal conductivity of various nanofluids. J. Mol. Liq. 2018, 265, 181-188. [CrossRef]

24. Parashar, N.; Aslfattahi, N.; Yahya, S.M.; Saidur, R. An Artificial Neural Network Approach for the Prediction of Dynamic Viscosity of MXene-Palm Oil Nanofluid Using Experimental Data; Springer: Berlin, Germany, 2020.

25. Sadri, R.; Ahmadi, G.; Togun, H.; Dahari, M.; Kazi, S.N.; Sadeghinezhad, E.; Zubir, N. An experimental study on thermal conductivity and viscosity of nanofluids containing carbon nanotubes. Nanoscale Res. Lett. 2014, 9, 151. [CrossRef]

26. Mesgari, S.; Taylor, R.A.; Hjerrild, N.E.; Crisostomo, F.; Li, Q.; Scott, J. An investigation of thermal stability of carbon nanofluids for solar thermal applications. Sol. Energy Mater. Sol. Cells 2016, 157, 652-659. [CrossRef]

27. Yashawantha, K.M.; Asif, A.; Babu, G.R.; Ramis, M.K. Rheological Behavior and Thermal Conductivity of Graphite-Ethylene Glycol Nanofluid. J. Test. Eval. 2019, 49, 4. [CrossRef]

28. Chen, W.; Zou, C.; Li, X. Application of large-scale prepared MWCNTs nanofluids in solar energy system as volumetric solar absorber. Sol. Energy Mater. Sol. Cells 2019, 200, 109931. [CrossRef]

29. Al-Kahtani, A.A.; Almuqati, T.; Alhokbany, N.; Ahamad, T.; Naushad, M.; Alshehri, S.M. A clean approach for the reduction of hazardous 4-nitrophenol using gold nanoparticles decorated multiwalled carbon nanotubes. J. Clean. Prod. 2018, 191, 429-435. [CrossRef] 
30. Mehrali, M.; Sadeghinezhad, E.; Akhiani, A.R.; Latibari, S.T.; Talebian, S.; Dolatshahi-Pirouz, A.; Metselaar, H.S.; Mehrali, M. An ecofriendly graphene-based nanofluid for heat transfer applications. J. Clean. Prod. 2016, 137, 555-566. [CrossRef]

31. Hajjar, Z.; morad Rashidi, A.; Ghozatloo, A. Enhanced thermal conductivities of graphene oxide nanofluids. Int. Commun. Heat Mass Transf. 2014, 57, 128-131. [CrossRef]

32. Mashali, F.; Languri, E.M.; Davidson, J.; Kerns, D.; Johnson, W.; Nawaz, K.; Cunningham, G. Thermo-physical properties of diamond nanofluids: A review. Int. J. Heat Mass Transf. 2019, 129, 1123-1135. [CrossRef]

33. Zheng, R.; Gao, J.; Wang, J.; Feng, S.P.; Ohtani, H.; Wang, J.; Chen, G. Thermal Percolation in Stable Graphite Suspensions. Nano Lett. 2012, 12, 188-192. [CrossRef]

34. Yu, W.; Xie, H.; Bao, D.J.N. Enhanced thermal conductivities of nanofluids containing graphene oxide nanosheets. Nanotechnology 2009, 21, 055705. [CrossRef]

35. Baby, T.T.; Ramaprabhu, S. Investigation of thermal and electrical conductivity of graphene based nanofluids. J. Appl. Phys. 2010, 108, 124308. [CrossRef]

36. Wang, F.; Han, L.; Zhang, Z.; Fang, X.; Shi, J.; Ma, W. Surfactant-free ionic liquid-based nanofluids with remarkable thermal conductivity enhancement at very low loading of graphene. Nanoscale Res. Lett. 2012, 7, 314. [CrossRef] [PubMed]

37. Oster, K.; Hardacre, C.; Jacquemin, J.; Ribeiro, A.P.; Elsinawi, A. Thermal Conductivity Enhancement Phenomena in Ionic Liquid-Based Nanofluids (Ionanofluids). Aust. J. Chem. 2019, 72, 21-33. [CrossRef]

38. Hosseinghorbani, A.; Mozaffarian, M.; Pazuki, G. Application of graphene oxide IoNanofluid as a superior heat transfer fluid in concentrated solar power plants. Int. Commun. Heat Mass Transf. 2020, 111, 104450. [CrossRef]

39. Fredlake, C.P.; Crosthwaite, J.M.; Hert, D.G.; Aki, S.N.; Brennecke, J.F. Thermophysical properties of imidazolium-based ionic liquids. J. Chem. Eng. Data 2004, 49, 954-964. [CrossRef]

40. Qeays, I.A.; Yahya, S.M.; Asjad, M.; Khan, Z.A. Multi-performance optimization of nanofluid cooled hybrid photovoltaic thermal system using fuzzy integrated methodology. J. Clean. Prod. 2020, 256, 120451. [CrossRef]

41. Abdallah, S.R.; Saidani-Scott, H.; Abdellatif, O.E. Performance analysis for hybrid PV/T system using low concentration MWCNT (water-based) nanofluid. Sol. Energy 2019, 181, 108-115. [CrossRef]

42. Aberoumand, S.; Ghamari, S.; Shabani, B. Energy and exergy analysis of a photovoltaic thermal (PV/T) system using nanofluids: An experimental study. Sol. Energy 2018, 165, 167-177. [CrossRef]

43. Sardarabadi, M.; Passandideh-Fard, M.; Heris, S.Z. Experimental investigation of the effects of silica/water nanofluid on PV/T (photovoltaic thermal units). Energy 2014, 66, 264-272. [CrossRef]

44. Sardarabadi, M.; Passandideh-Fard, M.; Maghrebi, M.-J.; Ghazikhani, M. Experimental study of using both $\mathrm{ZnO} /$ water nanofluid and phase change material (PCM) in photovoltaic thermal systems. Sol. Energy Mater. Sol. Cells 2017, 161, 62-69. [CrossRef]

45. Ebaid, M.S.Y.; Ghrair, A.M.; Al-Busoul, M. Experimental investigation of cooling photovoltaic (PV) panels using $\left(\mathrm{TiO}_{2}\right)$ nanofluid in water -polyethylene glycol mixture and $\left(\mathrm{Al}_{2} \mathrm{O}_{3}\right)$ nanofluid in watercetyltrimethylammonium bromide mixture. Energy Convers. Manag. 2018, 155, 324-343. [CrossRef]

46. Hendricks, J.H.; Van Sark, W.G. Annual performance enhancement of building integrated photovoltaic modules by applying phase change materials. Progress in Photovoltaics: Research and Applications. Prog. Photovolt. Res. Appl. 2013, 21, 620-630.

47. Ghadiri, M.; Sardarabadi, M.; Pasandideh-Fard, M.; Moghadam, A.J. Experimental investigation of a PVT system performance using nano ferrofluids. Energy Convers. Manag. 2015, 103, 468-476. [CrossRef]

48. Naguib, M.; Come, J.; Dyatkin, B.; Presser, V.; Taberna, P.L.; Simon, P.; Barsoum, M.W.; Gogotsi, Y. MXene A promising transition metal carbide anode for lithium-ion batteries. Electrochem. Commun. 2012, 16, 61-64. [CrossRef]

49. Wang, D.; Lin, Y.; Hu, D.; Jiang, P.; Huang, X. Multifunctional 3D-MXene/PDMS nanocomposites for electrical, thermal and triboelectric applications. Compos. Part A Appl. Sci. Manuf. 2020, 130, 105754. [CrossRef]

50. Naguib, M.; Mashtalir, O.; Carle, J.; Presser, V.; Lu, J.; Hultman, L.; Gogotsi, Y. Two-dimensional transition metal carbides. ACS Nano 2012, 6, 1322-1331. [CrossRef]

51. Naguib, M.; Halim, J.; Lu, J.; Cook, K.M.; Hultman, L.; Gogotsi, Y.; Barsoum, M.W. New two-dimensional niobium and vanadium carbides as promising materials for Li-ion batteries. J. Am. Chem. Soc. 2013, 135, 15966-15969. [CrossRef] 
52. Huang, K.; Li, Z.; Lin, J.; Han, G.; Huang, P. Two-dimensional transition metal carbides and nitrides (MXenes) for biomedical applications. Chem. Soc. Rev. 2018, 5109-5124. [CrossRef]

53. Lin, H.; Wang, X.; Yu, L.; Chen, Y.; Shi, J. Two-Dimensional Ultrathin MXene Ceramic Nanosheets for Photothermal Conversion. Nano Lett. 2017, 17, 384-391. [CrossRef]

54. Lei, J.C.; Zhang, X.; Zhou, Z. Recent advances in MXene: Preparation, properties, and applications. Front. Phys. 2015, 10, 276-286. [CrossRef]

55. Ji, J.; Zhao, L.; Shen, Y.; Liu, S.; Zhang, Y. Covalent stabilization and functionalization of MXene via silylation reactions with improved surface properties. FlatChem 2019, 17, 100128. [CrossRef]

56. Hunter, R.J. Zeta Potential in Colloid Science: Principles and Applications; Academic Press: Cambridge, MA, USA, 2013.

57. Wang, X.; Garnero, C.; Rochard, G.; Magne, D.; Morisset, S.; Hurand, S.; Chartier, P.; Rousseau, J.; Cabioc'h, T.; Coutanceau, $\mathrm{C}$; et al. A new etching environment $\left(\mathrm{FeF}_{3} / \mathrm{HCl}\right)$ for the synthesis of two-dimensional titanium carbide MXenes: A route towards selective reactivity vs. water. J. Mater. Chem. A 2017, 5, 22012-22023. [CrossRef]

58. Ghidiu, M.; Lukatskaya, M.R.; Zhao, M.-Q.; Gogotsi, Y.; Barsoum, M.W. Conductive two-dimensional titanium carbide 'clay' with high volumetric capacitance. Nature 2014, 516, 78. [CrossRef] [PubMed]

59. Xu, G.; Wang, X.; Gong, S.; Wei, S.; Liu, J.; Xu, Y. Solvent-regulated preparation of well-intercalated Ti3C2Tx MXene nanosheets and application for highly effective electromagnetic wave absorption. Nanotechnology 2018, 29, 355201. [CrossRef]

60. Chen, H.; Chen, N.; Zhang, M.; Li, M.; Gao, Y.; Wang, C.; Chen, G.; Du, F. Ti 3 C2T x MXene decorated with Sb nanoparticles as anodes material for sodium-ion batteries. Nanotechnology 2019, 30, 134001. [CrossRef]

61. Li, Y.; Zhou, X.; Wang, J.; Deng, Q.; Li, M.; Du, S.; Han, Y.H.; Lee, J.; Huang, Q. Facile preparation of in situ coated $\mathrm{Ti}_{3} \mathrm{C}_{2} \mathrm{Tx} / \mathrm{Ni}_{0.5} \mathrm{Zn}_{0.5} \mathrm{Fe}_{2} \mathrm{O}_{4}$ composites and their electromagnetic performance. RSC Adv. 2017, 7, 24698-24708. [CrossRef]

62. Chowdhury, A.; Thynell, S.T. Confined rapid thermolysis/FTIR/ToF studies of imidazolium-based ionic liquids. Thermochim. Acta 2006, 443, 159-172. [CrossRef]

63. Arifutzzaman, A.; Ismail, A.F.; Yaacob, I.I.; Alam, M.Z.; Khan, A.A. Stability investigation of water based exfoliated graphene nanofluids. IOP Conf. Ser. Mater. Sci. Eng. 2019, 488, 012002. [CrossRef]

64. Otanicar, T.P.; Phelan, P.E.; Prasher, R.S.; Rosengarten, G.; Taylor, R.A. Nanofluid-based direct absorption solar collector. J. Renew. Sustain. Energy 2010, 2, 033102. [CrossRef]

65. Clogston, J.D.; Patri, A.K. Zeta potential measurement. In Characterization of Nanoparticles Intended for Drug Delivery; Springer: Berlin, Germany, 2011; pp. 63-70.

66. Han, R.; Ma, X.; Xie, Y.; Teng, D.; Zhang, S. Preparation of a new 2D MXene/PES composite membrane with excellent hydrophilicity and high flux. RSC Adv. 2017, 7, 56204-56210. [CrossRef]

67. Padmanabhan, S.; Kim, M.; Blanch, H.W.; Prausnitz, J.M. Solubility and rate of dissolution for Miscanthus in hydrophilic ionic liquids. Fluid Phase Equilibria 2011, 309, 89-96. [CrossRef]

68. Mashali, F.; Languri, E.; Mirshekari, G.; Davidson, J.; Kerns, D. Nanodiamond nanofluid microstructural and thermo-electrical characterization. Int. Commun. Heat Mass Transf. 2019, 101, 82-88. [CrossRef]

69. Singh, V.; Gupta, M. Characterisation and Zeta Potential Measurements of CuO-Water Nanofluids. In Advances in Interdisciplinary Engineering; Lecture Notes in Mechanical Engineering; Springer: Singapore, 2019; pp. 741-747.

70. Said, Z.; Abdelkareem, M.A.; Rezk, H.; Nassef, A.M.; Atwany, H.Z. Stability, thermophysical and electrical properties of synthesized carbon nanofiber and reduced-graphene oxide-based nanofluids and their hybrid along with fuzzy modeling approach. Powder Technol. 2020, 364, 795-809. [CrossRef]

71. Chen, W.; Qiu, L.; Liang, S.; Zheng, X.; Tang, D. Measurement of thermal conductivities of $[\mathrm{mmim}] \mathrm{DMP} / \mathrm{CH}_{3} \mathrm{OH}$ and $[\mathrm{mmim}] \mathrm{DMP} / \mathrm{H}_{2} \mathrm{O}$ by freestanding sensor-based $3 \omega$ technique. Thermochimica Acta 2013, 560, 1-6. [CrossRef]

72. Akhavan-Zanjani, H.; Saffar-Avval, M.; Mansourkiaei, M.; Ahadi, M.; Sharif, F. Turbulent Convective Heat Transfer and Pressure Drop of Graphene-Water Nanofluid Flowing Inside a Horizontal Circular Tube. J. Dispers. Sci. Technol. 2014, 35, 1230-1240. [CrossRef]

73. Liu, J.; Wang, F.; Zhang, L.; Fang, X.; Zhang, Z. Thermodynamic properties and thermal stability of ionic liquid-based nanofluids containing graphene as advanced heat transfer fluids for medium-to-high-temperature applications. Renew. Energy 2014, 63, 519-523. [CrossRef] 
74. Lee, G.-J.; Rhee, C.K. Enhanced thermal conductivity of nanofluids containing graphene nanoplatelets prepared by ultrasound irradiation. J. Mater. Sci. 2014, 4, 1506-1511. [CrossRef]

75. Sang, L.; Ai, W.; Wu, Y.; Ma, C. Enhanced specific heat and thermal conductivity of ternary carbonate nanofluids with carbon nanotubes for solar power applications. Int. J. Energy Res. 2020, 44, 334-343. [CrossRef]

76. Tiznobaik, H.; Shin, D. Enhanced specific heat capacity of high-temperature molten salt-based nanofluids. Int. J. Heat Mass Transf. 2013, 57, 542-548. [CrossRef]

77. Ghazvini, M.; Akhavan-Behabadi, M.A.; Rasouli, E.; Raisee, M. Heat transfer properties of nanodiamond-engine oil nanofluid in laminar flow. Heat Transf. Eng. 2012, 33, 525-532. [CrossRef]

78. Oster, K.; Hardacre, C.; Jacquemin, J.; Ribeiro, A.P.C.; Elsinawi, A. Understanding the heat capacity enhancement in ionic liquid-based nanofluids (ionanofluids). J. Mol. Liq. 2018, 253, 326-339. [CrossRef]

79. Elhamarnah, Y.A.; Nasser, M.; Qiblawey, H.; Benamor, A.; Atilhan, M.; Aparicio, S. A comprehensive review on the rheological behavior of imidazolium based ionic liquids and natural deep eutectic solvents. J. Mol. Liq. 2019, 277, 932-958. [CrossRef]

80. Aravind, S.S.J.; Baskar, P.; Baby, T.T.; Sabareesh, R.K.; Das, S.; Ramaprabhu, S. Investigation of Structural Stability, Dispersion, Viscosity, and Conductive Heat Transfer Properties of Functionalized Carbon Nanotube Based Nanofluids. J. Phys. Chem. C 2011, 115, 16737-16744. [CrossRef]

81. Ko, G.H.; Heo, K.; Lee, K.; Kim, D.S.; Kim, C.; Sohn, Y.; Choi, M. An experimental study on the pressure drop of nanofluids containing carbon nanotubes in a horizontal tube. Int. J. Heat Mass Transf. 2007, 50, 4753. [CrossRef]

82. Adam, S.A.; Ju, X.; Zhang, Z.; Lin, J.; El-Samie, M.M.A.; Xu, C. Effect of temperature on the stability and optical properties of $\mathrm{SiO} 2-$ water nanofluids for hybrid photovoltaic/thermal applications. Appl. Therm. Eng. 2020, 175, 115394. [CrossRef]

83. Sardarabadi, M.; Passandideh-Fard, M. Experimental and numerical study of metal-oxides/water nanofluids as coolant in photovoltaic thermal systems (PVT). Sol. Energy Mater. Sol. Cells 2016, 157, 533-542. [CrossRef]

84. Lee, J.H.; Hwang, S.G.; Lee, G.H. Efficiency Improvement of a Photovoltaic Thermal (PVT) System Using Nanofluids. Energies 2019, 12, 3063. [CrossRef]

(C) 2020 by the authors. Licensee MDPI, Basel, Switzerland. This article is an open access article distributed under the terms and conditions of the Creative Commons Attribution (CC BY) license (http://creativecommons.org/licenses/by/4.0/). 